Geologic Reconnaissance of Semisopochnoi Island Western Aleutian Islands -Alaska

By ROBER'T R. COATS

$\therefore$ INVESTIGATIONS OF ALASKAN VOLCANOES

GEOLOGICAL SURVEY B ULLETIN 1028 - O

Prepared in cooperation with the Office, Chief of Engineers, U.S. Army

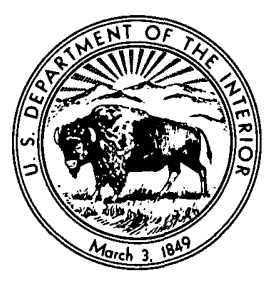


UNITED STATES DEPARTMENT OF THE INTERIOR

FRED A. SEATON, Secretary

\section{GEOLOGICAL SURVEY}

Thomas B. Nolan, Director 


\section{PREFACE}

In October 1945 the War Department (now Department of the Army) requested the Geological Survey to undertake a program of volcano investigations in the Aleutian Islands-Alaska Peninsula area. The first field studies, under the general direction of G. D. Robinson, were made during the years 1946-48. The results of the first year's field, laboratory, and library work were hastily assembled as two administrative reports, and most of these data have been revised for publication in Geological Survey Bulletin 1028. Part of the early work was published in $\mathbf{1 9 5 0}$ in Bulletin 974-B, "Volcanic Activity in the Aleutian Arc," and in 1951 in Bulletin 989-A, "Geology of Buldir Island, Aleutian Islands, Alaska," both by Robert R. Coats. During the years 1949-54 additional fieldwork was carried out under the direction of $\mathrm{H}$. A. Powers. Unpublished results of the early work and all of the later studies are being incorporated as parts of Bulletin 1028.

The geological investigations covered by this report were reconnaissance. The factual information presented is believed to be accurate, but many of the tentative interpretations and conclusions will be modified as the investigations continue and knowledge grows.

The investigations of 1946 were supported almost entirely by the Military Intelligence Division of the Office, Chief of Engineers, U. S. Army. From 1947 until 1955 the Departments of the Army, Navy, and Air Force joined to furnish financial and logistic assistance. The Geological Survey is indebted to the Office, Chief of Engineers, for its early recognition of the value of geologic studies in the Aleutian region, and to the several military departments for their support. 


\section{CONTENTS}

Preface ........ Page

Abstract _-_______- 477

Introduction …_-_._.

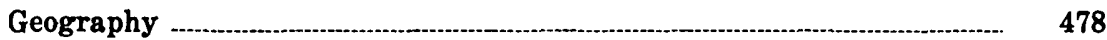

Location and size

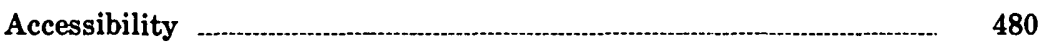

Topography and drainage._._._. 480

Geology -....... 481

Old volcano-Pochnoi volcanics..._._._._._. 481

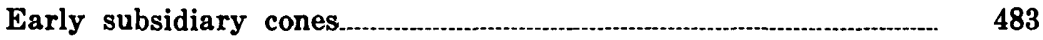

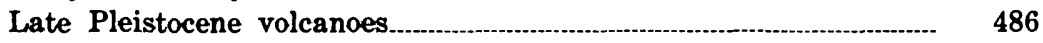

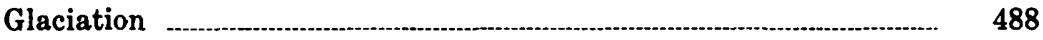

Pumice eruption and the formation of the caldera

Volume and mode of eruption

Early postcaldera eruptions

Recent cones ...-_- 495

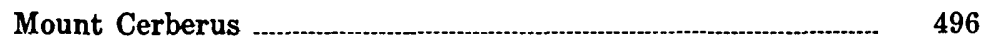

Lakeshore Cone ...._._. 498

Sugarloaf Peak ..._._._- 498

Unconsolidated deposits _..._. $\quad 500$

Alluvium, eluvium, and talus. $\quad 500$

Sand dunes ................. 500

Geologic history $\quad 501$

Historic volcanic activity

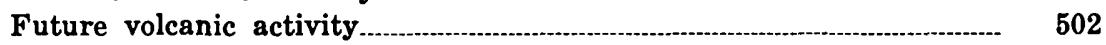

Petrography _._-_._- 503

Pochnoi volcanics .

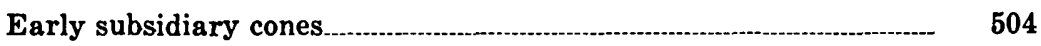

Late Pleistocene volcanoes

Pumice eruption …_- 505

Recent cones ............. 505

Chemistry -

Differentiation at Semisopochnoi

Rarer constituents _._._. 512

Literature cited -

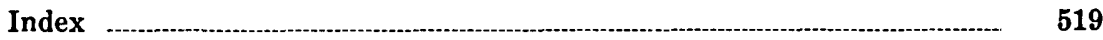




\section{ILLUSTRATIONS}

Plate 59. Geologic map and section of Semisopochnoi Island, Aleutian Islands

In pocket

60. A. Gentle southward-sloping remnant of the old Pochnoi cone. $B$. Dissected cone of Ragged Top.

Facing

482

61. Aerial view of the southeast coast of Semisopochnoi Island Facing

62. A. View of flat-lying lava flows. $B$. Roche moutonnée on east side of valley between Anvil Peak and Perret Ridge Facing

63. A. Gully near Threequarter Cone. $B$. Dacitic pumice_Facing

64. Aerial view of the southwest coast of Semisopochnoi Island Facing

65. View looking southward from the west side of Ragged Top Facing

66. Panorama of Mount Cerberus from the north and northeast Facing

67. A. Lava flow from Mount Cerberus. $B$. Lava toes_...Facing

68. A. Agglutinate. $B$. View on south side of Sugarloaf Peak Facing

FIGURE 73. Index map of central Aleutian Islands, showing position of Semisopochnoi Island

74. Variation diagram for volcanic rocks from Semisopochnoi Island

75. Relation of magnesia ( $\mathrm{MgO}$ ), iron (as $\mathrm{FeO}$ ), and alkalies $\left(\mathrm{Na}_{2} \mathrm{O}+\mathrm{K}_{2} \mathrm{O}\right)$ in volcanic rocks from Semisopochnoi Island

76. Relations of al, alk and $c+f m$ in volcanic rocks from Semisopochnoi Island, plotted in 2 sections of the Niggli tetrahedron that include the alk-al edge

\section{TABLES}

TABLE

1. Major and minor constituents of $\mathbf{1 5}$ volcanic rocks from Semisopochnoi Island, with norms and Niggli numbers...- 


\title{
GEOLOGIC RECONNAISSANCE OF SEMISOPOCHNOI ISLAND, WESTERN ALEUTIAN ISLANDS, ALASKA
}

\author{
By ROBERT R. COATS
}

\begin{abstract}
Semisopochnoi Island, the largest of the young volcanic islands of the western Aleutians, is the easternmost of the Rat Island group, and is near the southern extremity of the great Aleutian arc. The island consists entirely of volcanic rocks, and sediments derived from them, of probable Pleistocene and Recent age. It is a large shield-shaped basaltic volcano, with parasitic cones of andesite and basalt. The higher, central part, which once supported extensive glaciers, subsequently collapsed to form an elliptical caldera almost 5 miles in greatest width. The collapse was attended and, at least in part, caused by the extrusion in the form of glowing clouds of large volumes of pale-gray dacitic pumice and ash. In most of the present valleys there are thick deposits of this pumice and ash, but in the parts of the island that were sheltered from this flood of hot, gas-charged pumic and ash there are only thin layers. After the collapse, eruptions of basalt and basaltic pyroclastic material took place in the caldera. Recent composite cones of basaltic composition, 2 large and 1 small, have erupted intermittently and have built up domes of lava, the largest of which is nearly 3,000 feet high. The lava flows emitted from these cones have nearly filled the caldera floor, and cover a considerable area in the southeastern quarter of the island.

The rocks are generally poor in phenocrysts; the principal minerals are intermediate to calcic plagioclase, olivine, hypersthene, clinopyroxene, usually augite in the phenocrysts and augite or pigeonite in the groundmass, magnetite or ilmenite, apatite, quartz, and orthoclase. Hornblende is present only in the dacitic tuff erupted at the time of the formation of the caldera. The analyses indicate that the alkali-lime index is about 59 , hence the province is calcalkaline, thus differing perceptibly in this respect from other Aleutian volcanoes from which extensive rock series have been analyzed. The relations of the oxides make it evident that the rocks of Semisopochnoi are somewhat enriched in iron in the intermediate composition range, thus departing slightly in this regard from the normal basalt-andesite-dacite sequence. The content of a few of the minor constituents in the rocks of Semisopochnoi differs significantly from that of the rocks of other western Aleutian islands.
\end{abstract}




\section{INTRODUCTION}

Semisopochnoi Island, the largest of the young volcanic islands of the western Aleutians, is the easternmost of the Rat Island group, and is about 40 statute miles north-northwest of Constantine Harbor on the east end of Amchitka Island. Its proximity to the harbor and to Amchitka Air Force Base, which were being used in 1947, made the island easy to reach, and the volcanic activity that had recently occurred on it invited early study.

No geologic work seems to have been done on Semisopochnoi Island prior to the study made by me. My field assistant, Will F. Thompson, Jr., and I were landed on a small beach, just west of the south point of the island, on August 22, 1947, and re-embarked from the same beach on September 11. Much additional information about areas not reached during our study has been furnished by Howard A. Powers, who was stationed on board the USCGS ship Pioneer for one week in May 1949, and had several opportunities to land on the northeast, north, and west sides of the island.

The work would not have been possible without the friendly assistance received from Maj. John Davis, CAC, port commander, Adak, from John Mack, master of the FS 244, on which we were transported from Adak to Semisopochnoi, and from Dr. H. D. Gray, of the Fish and Wildlife Service ship Brown Bear, which took us from Semisopochnoi to Amchitka. The cooperation of Lt. Col. R. E. Ware, Corps of Engineers, post engineer, Adak, and of Commdr. J. M. Oseth, commander Naval Operating Base, Adak, is also gratefully acknowledged. We are also indebted to Commdr. B. Moore, Jr., commander Naval Air Facility, Adak, for arranging for aerial reconnaissance of the island, and to Capt. $H$. L. Underwood, Signal Corps, for assistance in obtaining radiocommunication facilities.

\section{GEOGRAPHY}

\section{LOCATION AND SIZE}

Semisopochnoi Island (fig. 73) lies near the southernmost point of the Aleutian arc of active volcanoes, between long $179^{\circ} 28^{\prime}$ and $179^{\circ} 45^{\prime} \mathrm{E}$., and between lat $52^{\circ} 02^{\prime}$ and $51^{\circ} 53^{\prime} \mathrm{N}$. It is 12.4 miles long by 10.6 miles wide and, according to a planimetric measurement by Harold Drewes, has an area of 78.3 square miles. 


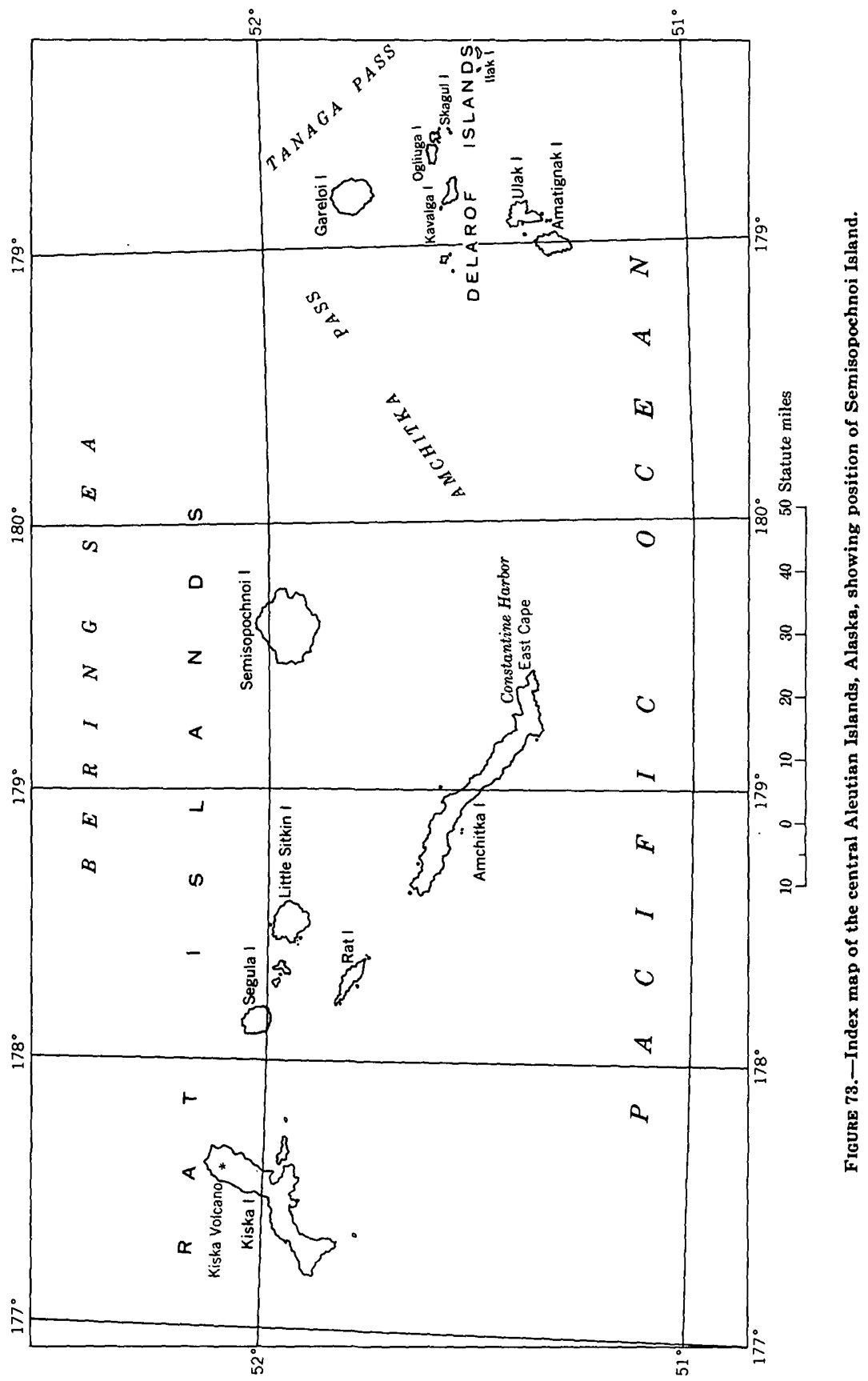




\section{ACCESSIBIIITY}

Most of the island is bordered by high rocky cliffs and many offshore reefs. Two broad sandy beaches on the southeast and two on the southwest sides of the island offer easy landing places when the surf is not too high. The island has a number of narrower, steeper, and more bouldery beaches, and even these may be used under favorable circumstances. Several trappers' cabins and the remains of a U.S. Army weather station offer shelter of a kind.

\section{TOPOGRAPHY AND DRAINAGE}

The topography of Semisopochnoi Island (pl. 59) has a greater degree of symmetry and simplicity than that of most Aleutian Islands of its size. The outer slopes consist of radially disposed, maturely dissected ridges and intervening valleys that are partly steep walled. Some of the valley floors are flattened by alluviation, some are covered with exceedingly rough-textured flows of block lava, and some are partly filled with a youthfully dissected mass of soft volcanic material. The radial ridges (pl. 60A) terminate inland in a steep scarp that is 200 to 1,000 feet high and that faces a partly obliterated elliptical central depression. This depression is about 3.8 by 4.7 miles in diameter and its long axis trends northeastward. Such central depressions, more or less circular in form, are common in volcanic regions; the example on Semisopochnoi will hereafter be referred to as the caldera, since it conforms closely to the definition of the term "caldera" as given by Williams (1941, p. 242). It is one of those "large volcanic depressions more or less circular . . . in form, the diameters of which are many times greater than those of the included vent or vents." Above the general surface of the peripheral ridges and valleys rise several composite volcanic cones in various stages of dissection.

The highest of these cones is Anvil Peak, which attains an altitude of 3,867 feet. Sugarloaf Peak, a conspicuous slightly dissected cone, 2,808 feet high, and the parasitic cone on its south flank form a well-known landmark near the southeast coast. Farther to the north, a steep and deeply dissected cone, Ragged Top, is also a conspicuous topographic feature. The central caldera has been partly filled, and its walls partly concealed, by the products of later eruptions, which have resulted in the erection of several volcanic cones, the largest of which is Mount Cerberus. As Mount Cerberus is southwest of the center of the 
caldera, the lowest point of the depression lies close to the frowning cliffs on the north side. This part of the depression is occupied by a lake, Fenner Lake, about 2 miles long and somewhat less than half a mile wide at the widest. The outlet of the lake, which is at an altitude of 250 feet, is a substantial stream of clear water, that flows southward between alluvial banks for about $11 / 2$ miles, and then enters a small pond. This pond, about 300 yards long, has been formed by the damming of the stream behind one of the latest lava flows from Mount Cerberus. The stream, confined between the flow and the northeast wall of the valley, plunges in several small falls down to the alluvial floor of the valley near the snout of the lava flow and then meanders toward the sea, which it enters about 2 miles east of the summit of Sugarloaf.

Fenner Creek, the outlet stream just described, is the largest stream on the island and the most constant in its flow, being stabilized not only by Fenner Lake, but by several large springs that feed its upper part. Its total flow, at a point just above the mouth, was estimated in August 1947 to be 250 cubic feet per second. Other streams, which occupy alluviated valleys near sea level, carry substantial amounts of water at relatively steady rates of flow, but the streams that cross highly permeable lava fluctuate widely, and often run dry except when supplied by rain or melting snow.

\section{GEOLOGY}

\section{OLD VOLCANO-POCHNOI VOLCANICS}

The oldest rocks of Semisopochnoi Island are a sequence of tuff-breccia, lava, and agglomerate, and a minor amount of sandstone, herein called the Pochnoi volcanics, because the best exposures appear to be west and north of Pochnoi Point. These rocks were apparently erupted by a volcano, which had approximately the same dimensions as the present island, whose center of eruption lay somewhere within the area of the present central depression.

In deduced form the old volcano corresponds fairly well with that of typical Hawaiian shield volcanoes. This resemblance, however, is chiefly in outward form and in the low dip of the materials that make up the structure, rather than in the type of materials, which on Semisopochnoi seem to be largely basaltic pyroclastic material and minor andesitic flows, rather than the 
basaltic flows typical of Hawaii. The gentle dips of the pyroclastic rocks of the Pochnoi volcanics can perhaps be attributed to submarine accumulation. Alternatively, and perhaps more accurately, the fundamental volcanic structure of the island might be referred to as a submarine tuff cone, the word "tuff" being used in its most general sense.

The rocks of this unit are now chiefly exposed in the northeast, south, and southwest parts of the island, outside of the central lowland; elsewhere they are covered by the products of later volcanic eruptions. Many places mapped as Pochnoi volcanics are covered by a relatively thin, uneven layer of volcanic ash; this ash is either the light-gray dacitic ash of the calderaforming eruption or the darker colored basaltic ash erupted from the Recent volcanoes, and has not been separately mapped. In the walls of the caldera in the northwest and northeast sectors, the Pochnoi volcanics extend to heights of 1,700 feet.

The oldest material recognized is a poorly sorted tuff-breccia that dips gently seaward. The fragments are mostly angular, and the largest are several feet in diameter. The fragments identified range in composition from olivine basalt through olivine-hypersthene basalt to hypersthene basalt. Yellow and brown stains, due to the development of limonitic and palagonitic alteration products, are common.

At Pochnoi Point a widespread flow of olivine basalt is prominently exposed. Along the north coast of Pochnoi Point, about $11 / 2$ miles south of Northeast Point, the lowest rock exposed in the sea cliff is basaltic lava. Its top is an eroded plane surface, possibly a wave-cut bench, on which is horizontally bedded lenticular indurated sandstone. Further west, in the eastward facing cliff between 2,000 and 1,000 yards south of Northeast Point, the sandstone is covered by relatively unconsolidated scoria agglomerate that underlies the surface for some distance inland. A line of springs marks the contact of the agglomerate on the indurated sandstone in the sea cliff. The sandstone is composed chiefly of black basaltic and yellow palagonitized glassy fragments, but includes some short threads of palagonite that are believed to represent lava fountain debris. The sand is medium olive brown (5Y 4/4) ${ }^{1}$ and ranges in grain size from mediumsized sand to coarse granules. According to Powers (oral communication, 1949) these rocks were apparently deposited in

\footnotetext{
1 Symbols in parentheses after color names refer to Munsell system. Comparison has been made with the Rock-Color Chart (National Research Council, 1948).
} 


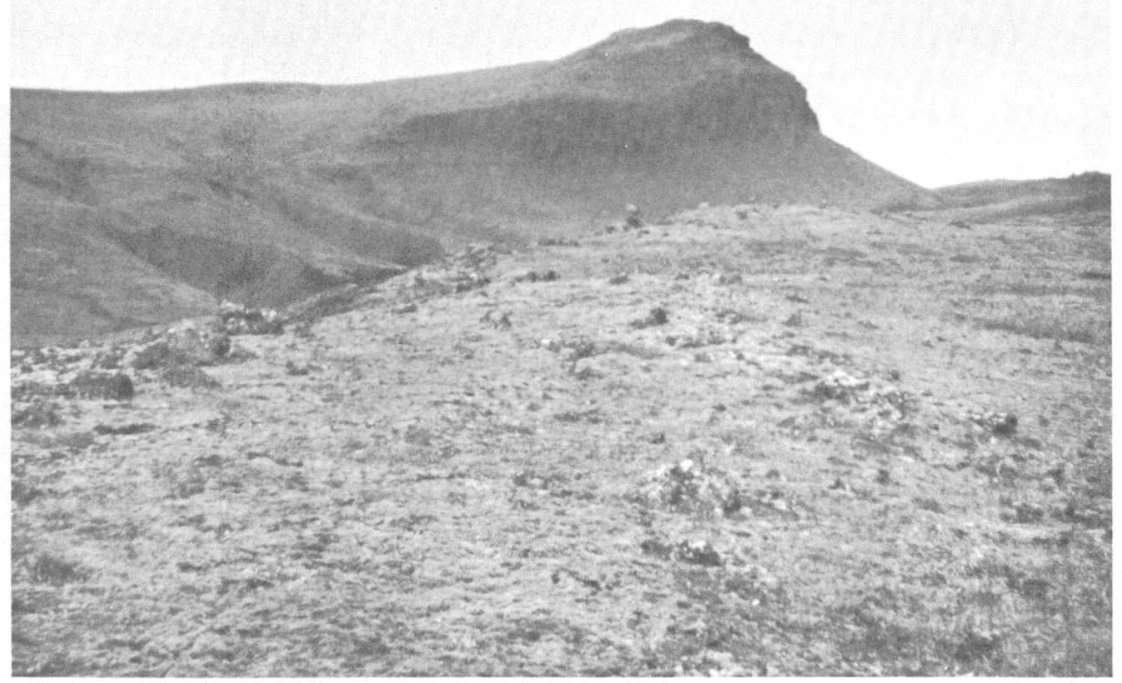

A. GENTLE SOUTHWARD.SLOPING REMNANT OF THE OLD POCHNOI CONE

Exposed rock is principally tuff-breccia.

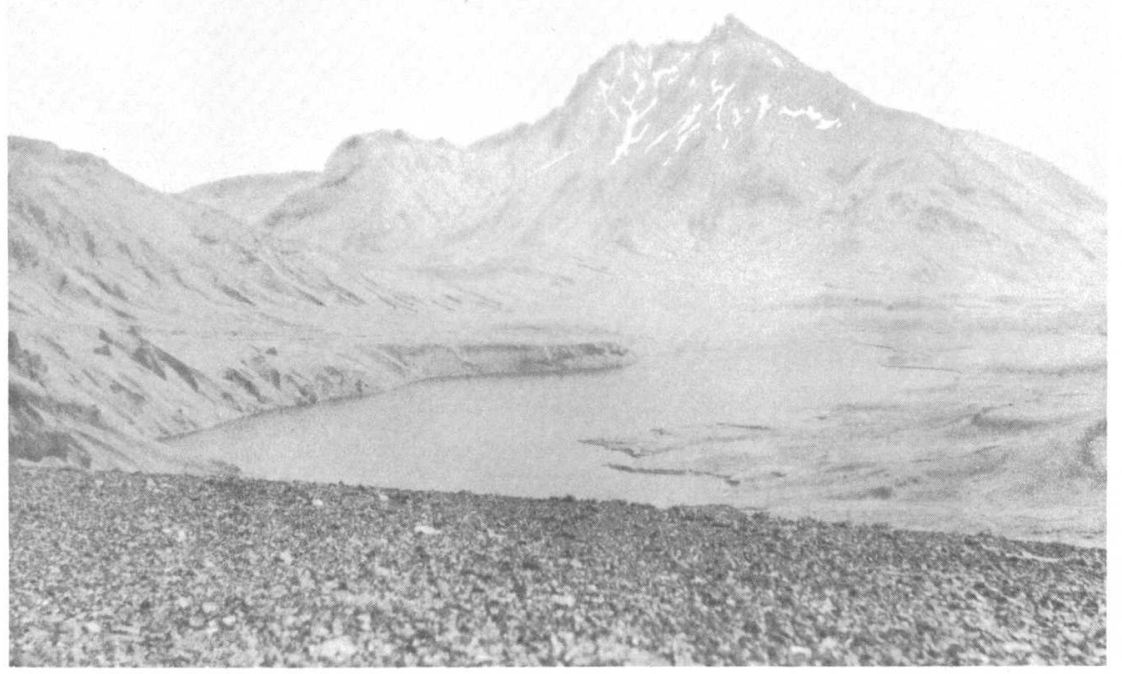

$B$, DISSECTED CONE OF RAGGED TOP

View is from a point south of Anvil Peak. Fenner Lake (center) is retained on the left by caldera wall, and on the right by lava flows and alluvial fans. 


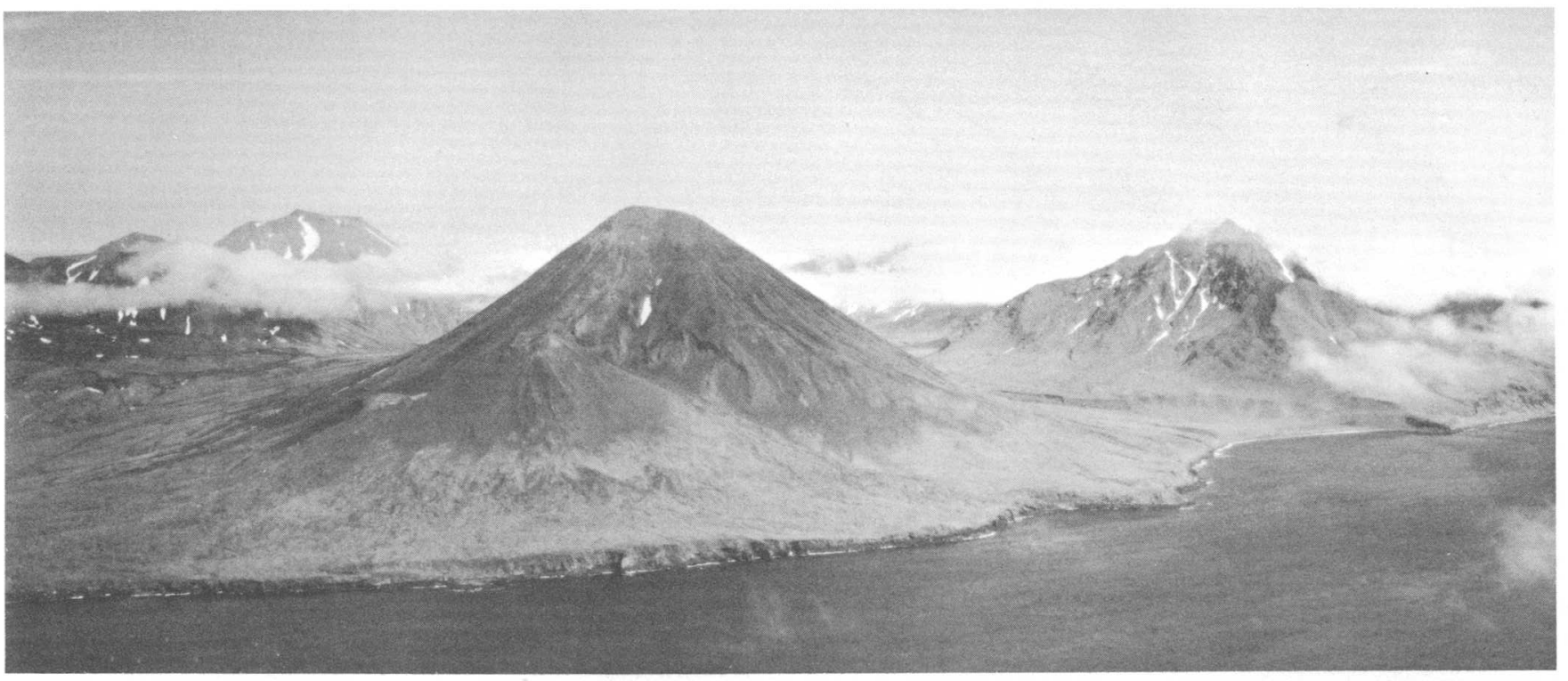

AERIAL VIEW OF THE SOUTHEAST COAST OF SEMISOPOCHNOI ISLAND

Shows Sugarloaf Peak (center) with its double parasitic cone (foreground) that was the source of one of the more recent flows. Ragged Top (right) shows a remnant of constructional surface on its seaward face. Photograph by U.S. Navy. 
partly sheltered embayments on the margin of the island during the time of eruption of the Pochnoi volcanics and during a stand of the sea higher than the present one.

In the sector of the old Pochnoi cone about a mile southwest of Mount Cerberus (pl. 60A), the predominant types of lava are platy to vesicular partly glassy augite-hypersthene andesite that is from medium light gray $(N 6)$ to medium dark gray $(N 4)$. Similar platy lava flows crop out between Sugarloaf Peak and the flood of younger lava from Cerberus that reaches the sea west of Sugarloaf. The headland about 2 miles south of Tuman Head seems to have been an isolated center of eruption, somewhat younger than the main cone, judging from the steep outward dips of the flows and pyroclastic rocks that rest upon the gently dipping older Pochnoi volcanics.

The rocks referred to in this unit may include unrecognized parasitic eruptive centers on the flank of the major volcano, similar to those separately described under the next two headings.

\section{EARLY SUBSIDIARY CONES}

The older subsidiary cones that once diversified the slopes of Pochnoi Volcano have been deeply dissected, and are now mere ruins of their former selves-some of them very picturesque ruins. The most spectacular of these old cones is Ragged Top (pl. 60B), whose altitude, 2,965 feet, is probably not far from the maximum original height. As shown in plate 61, in which Ragged Top is the peak on the right-hand side, parts of what seem to be the original constructional surface of the cone are preserved. Such topographic features have been called planezes by Cotton (1944, p. 365), following de Martonne. The exposed core of the volcanic plug forms what appears in plates $60 \mathrm{~B}$ and 61 to be the highest peak of the mountain.

What may be the oldest of the observed flows from Ragged Top is a flow 20 feet thick of medium-gray olivine basalt that forms the point just east of the outlet of Fenner Creek. The lower surface of the flow is slightiy slaggy and scoriaceous, and the tuffaceous agglomerate beneath has been reddened for a thickness of as much as 8 feet; this agglomerate, of which about 80 feet is exposed, is apparently conformable with the flow. About 90 percent of the total volume consists of fragments larger than one-fourth inch, and 50 percent of the fragments range in greatest dimensions from 11/4 inches to 6 feet. Most of the fragments 
are red to black lapilli of scoriaceous basalt, with subordinate subrounded fragments of accessory compact basalt. A foot-long fragment of a bipolar bomb was seen.

Another flow from Ragged Top, exposed in the caldera wall on the shoulder overlooking the central lowland, is a medium-gray ( $N$ 5) porphyritic augite-hypersthene andesite with a streaky texture.

To the north of the main peak, a number of bombs of varying composition and texture have been brought down to the floor of a cirque by disintegration of the weak pyroclastic rocks in which they were embedded. Some of the bombs and compact breadcrusted reheated blocks are as much as 3 feet in diameter. The bombs have a scoriaceous and irregular exterior and a compact interior, locally with cores of gabbroic texture. Nearly all these bombs are largely or partly glassy augite-hypersthene andesite and olivine-hypersthene-augite andesite. Some of the bombs and blocks are bleached and solfatarized, but it does not seem necessary to infer that they were erupted after their alteration, as the material has been reworked by glaciers since its eruption.

Another of the clder cones, at an altitude of 1,405 feet, lies southwest of Fenner Creek valley and north of the summit of Sugarloaf Peak. The material that crystallized in the throat of the old volcano now stands in steep cliffs, which face the outlet valley and the snout of one of the latest flows from Mount Cerberus. This is a light-gray $(N 7)$ fine-grained phanerocrystalline olivine microgabbro. Slight deuteric alteration has produced some albite and nontronite, which line cavities and replace bytownite and olivine respectively. A finer grained phase of the rock in the neck is a medium-gray ( $N$ 5) compact porphyritic olivine basalt, which perhaps represents a later diking of the coarser gabbro described above.

The material that makes up the main structure of this cone north of the summit of Sugarloaf is partly tuffaceous agglomerate, that contains bombs and accessory fragments, mainly of black vesicular basalt, as much as 10 inches in diameter. These pyroclastic rocks dip outward from the neck at angles that locally exceed $30^{\circ}$. Elsewhere the pyroclastic material may be considered a brecciaceous tuff that contains a few angular compact to scoriaceous basaltic fragments as much as 8 inches in diameter in a matrix of sand and silt grade. The beds of pyroclastic rock are as much as 20 feet thick. Lava flows make up only a small part of the cone; typical of these is a flow 4 feet thick of medium-brownish-gray $(5 R 5 / 1)$ aphanitic olivine basalt that 
contains a few small phenocrysts of plagioclase and many flattened vesicles.

Tuman Head seems to be made up of flows and pyroclastic material erupted from two distinct centers not far apart; the older center is nearer the coast. Each of the cones is about nine-tenths pyroclastic material that contains many bombs which generally are 1 or 2 inches, rarely as much as several feet in diameter; the larger ones are generally broken. Interbedded with the pyroclastic rocks are a few stringy flows; most of these are 10 to 20 feet thick, but the lowest one exposed is about 30 feet thick. The flows generally consist of compact medium-gray to medium-lightgray ( $N 5$ to $N 6$ ) seriate olivine basalt and olivine-hypersthene basalt; some contain numerous phenocrysts of plagioclase, and less numerous ones of olivine and augite. Another center of eruption, active somewhat later than the one that liberated most of the rocks of the northern part of Tuman Head, is represented by a peak 1,180 feet high about 1.6 miles east of South Tuman Point. The nature of the eruptions and the types of rocks appear to be similar to those of the older cone.

A peak 1,389 feet high about 3 miles east-southeast of South Tuman Point, is a remnant of another center, the crater of which has been completely destroyed by erosion.

What seems to be the remnants of two separate basaltic cones, rather similar in eruptive products to those of Tuman Point, form the 1,412-foot summit south of North Head, and the 1,193foot summit three-fourths of a mile west of Northeast Point. Subsequent erosion has enlarged the constructional valley between the two cones and the valley is now partly filled with later rocks.

Perret Ridge, the rugged comb ridge that forms the high mountain wall northeast of Fenner Lake, is probably, judging from the dips of its flows, the remnant of a steep cone that once surmounted the main shield volcano which forms the basic structure of the island. What is interpreted as a minor parasitic cone was apparently formed at about the same time as the cone of Perret Ridge over a vent lying just north of the west end of Fenner Lake; it is now exposed as a massive buttress in the steeply cliffed walls of the caldera. The only sample examined in thin section is a medium-gray vesicular olivine basalt that contains scarce hypersthene. The pyroxene of the groundmass is pigeonitic. 
The only evidence of the age of the Pochnoi volcanics, which are unfossiliferous, and the material of the associated subsidiary cones is the relation of these rocks to glacial erosion (see p. 488). Inasmuch as these rocks have been glacially eroded, and the volcanic structures have been dissected by cirques and U-shaped valleys, it is inferred that neither series can be younger than the latest glaciation, and the possibility of late Tertiary age cannot be excluded.

\section{LATE PLEISTOCENE VOLCANOES}

Three cones classed as late Pleistocene are distinguished from the earlier ones by their being less eroded. There is evidence that the period of formation of some of them overlapped that of the caldera. Two of the cones, altitude 914 and 1,705 feet, are cinder cones, or scoria rings, of basaltic material, and lie on a line that trends southeastward from the northern point of Tuman Head to the westernmost cone of Mount Cerberus. The third cone is Anvil Peak, 3,867 feet high, the highest point on the island; there is a parasitic cone, 3,230 feet high, southwest of the main summit.

Anvil Peak, partly because of its greater height and partly because of the smaller permeability of its rocks, has been eroded more deeply than the two smaller cones. Its more northerly and higher summit is bordered on all sides by wide, steep-floored barrancos in which the snow lies late in the year, and the effects of nivation and frostwork are evident. The highest point of the mountain seems to be a part of the old rim of Anvil Peak crater, somewhat diminished in height by erosion. North of this point is a nearly flat surface (pl. 62A) that is roughly circular in outline and about 1,200 feet in diameter. This surface is underlain by six flat-lying lava flows that represent the filling of the old crater of Anvil Peak; each flow is about 20 feet thick, and they are exposed in the cliff that bounds this high plateau on all sides but one.

The flows rest upon yellow and red palagonitic tuffs that are traversed by many irregular dikes. Overlying these thick lightcolored flows in the old crater is a flow 4 feet thick of highly vesticular, almost pumiceous, olivine basalt. The lighter color of the less vesicular flows beneath is apparently due to incipient fumarolic action on exposed joint faces, as these rocks also are olivine basalt, with relatively few large vesicles and conspicuous crystals of bytownite, augite, and olivine. The surface of the flat area is covered with loose material, much of which obviously is pyroclastic, including black basaltic lapilli and a few cored 
bombs. The core of one of the bombs apparently was originally sandstone, and is now converted to an aggregate of tridymite and pale-brown glass that is cut by veinlets of black glass. In thin section this glass appears darker brown and is seen to contain small well-formed prisms of pyroxene that range from augite to pigeonite. The glass also encloses a few corroded relicts of quartz. The rind of the bomb is glassy basalt and has phenocrysts of bytownite. Such accidental specimens of the underlying basement are seldom brought up by the Aleutian volcanoes.

A small tuff ring about $21 / 2$ miles east of South Tuman Point is 914 feet high and appears to be late Pleistocene. This structure has an external diameter of more than four-tenths of a mile, and the crater floor is about half that width. The crater rim is notably asymmetrical; its lowest point is only about 90 feet above the bottom of the crater, and its highest point is 384 feet above the bottom.

The mound of scoria, 1,705 feet high, about $11 / 2$ miles northwest of the nearest cone of Mount Cerberus is also strongly asymmetrical and is called Threequarter Cone. One of its latest eruptive phases was the extrusion of a small lava flow that barely overtopped the low northwestern side of the crater. The almost wholly pyroclastic material erupted from this center ranges in structure from scoriaceous to compact. It consists of dark-gray or black to dusky-red glassy to cryptocrystalline augite andesite, containing sporadic hypersthene and olivine.

The asymmetry of both these cones probably was caused by strong winds blowing constantly from a single direction during a single brief eruptive episode.

Determining the relation of these late. Pleistocene cones to the formation of the caldera is somewhat difficult. Both Anvil Peak and Threequarter Cone are transected by the walls of the caldera, whose collapse was apparently due to the extravasation of a great volume of the dacitic pumice described on page 489 ; yet the material of Threequarter Cone definitely, and that of Anvil Peak possibly, overlies this pumice. In Threequarter Cone, the relations are so well exposed on the wall of the caldera that there can be no doubt of the relative age of the two formations. The material from Anvil Peak, on the other hand, that was seen to overlie the dacitic pumice may not have arrived at that position directly by eruption; a great mass of it may have slid down the slope of the volcano, which is considerably dissected. It is also possible, as will be shown later, that the caldera was enlarged by subsidence after it was first formed, and that the walls now 
enclose a greater area than they did when the dacite pumice was being erupted, or when the caldera first collapsed, or at the time of the last eruptions of the late Pleistocene.

\section{GLACIATION}

Evidence for the glaciation of Semisopochnoi Island is rather scanty. Aside from physiographic evidence, such as cirque basins and U-shaped valleys, the exposure of glacially shaped and striated bedrock found on the rim of the caldera (pl. 62B) is the most substantial bit of evidence. No moraines or glacial tills were found in the course of the mapping, but any that may have existed must have been largely concealed beneath later volcanic and solifluctional deposits.

Characteristic cirquelike valley heads may be found on several of the higher peaks, particularly on Ragged Top (2,965 feet) and Perret Ridge (2,916 feet), though even on these the form of the cirques is relatively immature, lacking the flat or retrograde floor, and with headwall slopes of at most $60^{\circ}$. A few steepwalled, flat-floored valleys, remarkably cirquelike in form, have been found at low altitudes on Tuman Head, where the valley floors have altitudes of 300 to 500 feet above sea level, and on the headland just south of Tuman Head. Similar-shaped consequent valleys have been formed by stream erosion in the Hawaiian Islands (Hinds, 1925) ; possibly some of the low-level valleys on Semisopochnoi are similar in origin to the Hawaiian valleys. Similar valley forms, at similar altitudes, also have been formed, however, in northward-facing valley heads on Kiska Island; here the details of the glacial modeling are still visible, because there was no later volcanic activity in that part of the island.

Yet the much higher summit of Anvil Peak (3,867 feet) shows the effects of nivation rather than cirque erosion. The valley profiles differ but little from the average profile of the surface of a young volcanic cone. The lower slopes on the west side are modified by festoons of arcuate ridges; these ridges have not been examined in the field, but they closely resemble the solifluctional terraces common in periglacial areas.

This contrast between the degree of glaciation on the lower peaks and that on the highest peak of the island suggests strongly that Anvil Peak erupted periodically during the period of glaciation, and thus maintained, through continual rejuvenation by fresh accretions of volcanic material, a youthful volcanic profile. 


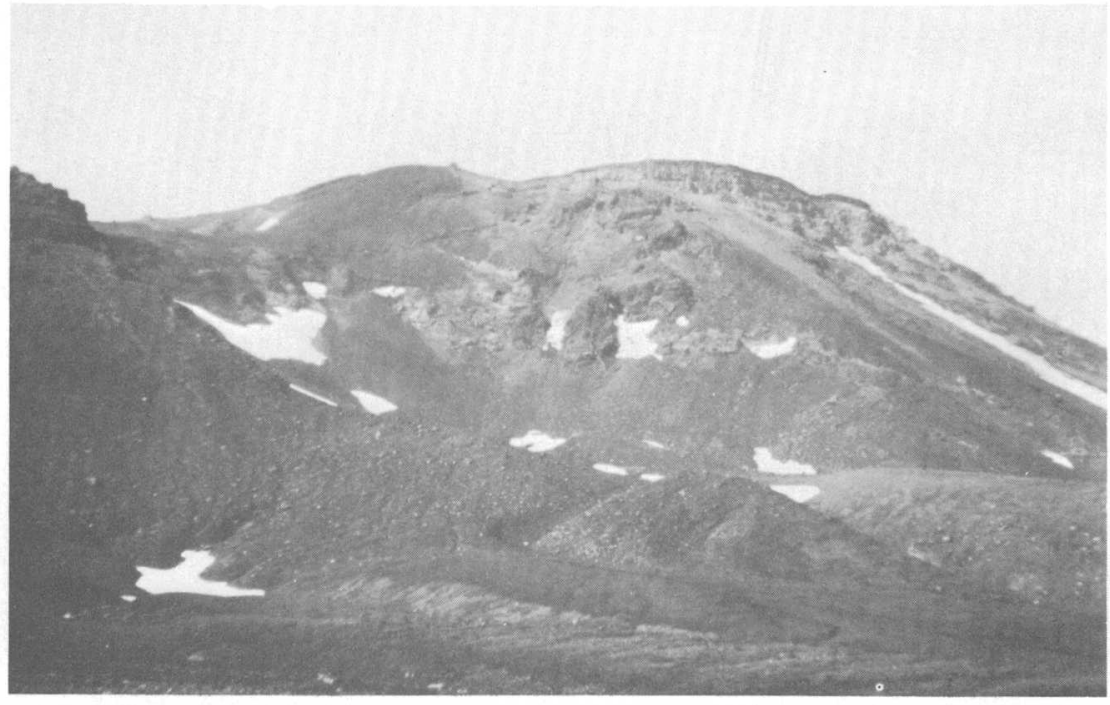

A. VIEW OF FLAT-LYING LAVA FLOWS

Flows are left after erosion of the crater they once filled on the north flank of Anvil Peak.

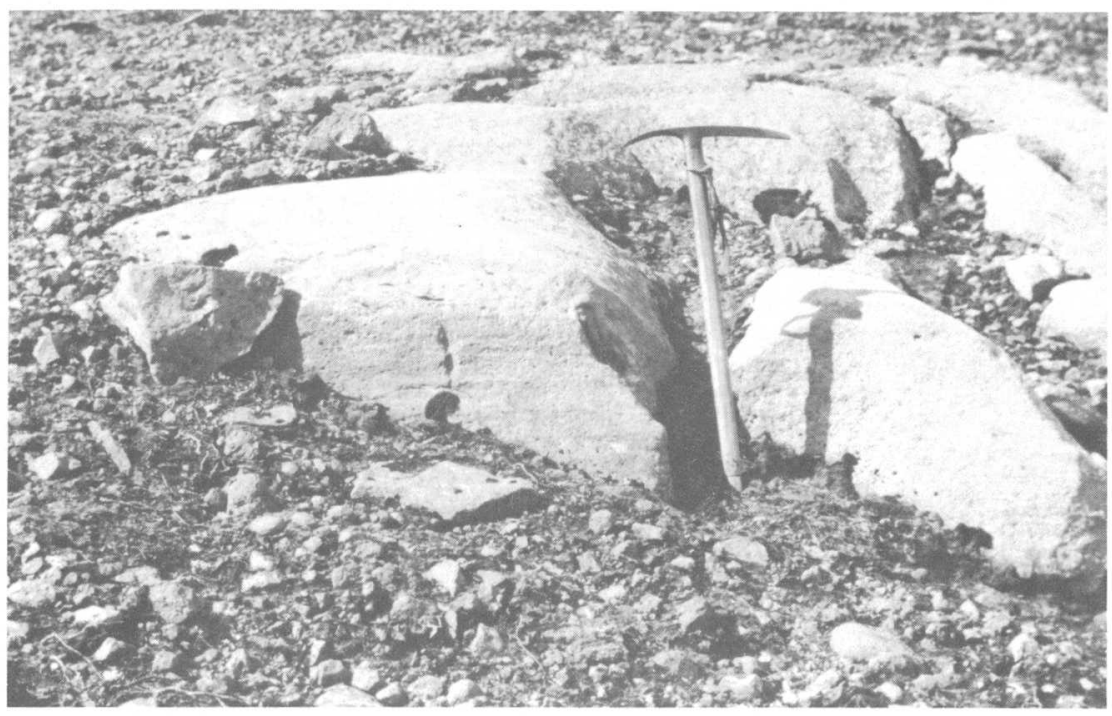

B. ROCHE MOUTONNEE ON EAST SIDE OF VALLEY BETWEEN ANVIL PEAK AND PERRET RIDGE View is a few hundred feet north of the caldera wall. Stoss (left) side faces toward the caldera. The trend of the striations is $\mathrm{N} .20^{\circ} \mathrm{E}$. 


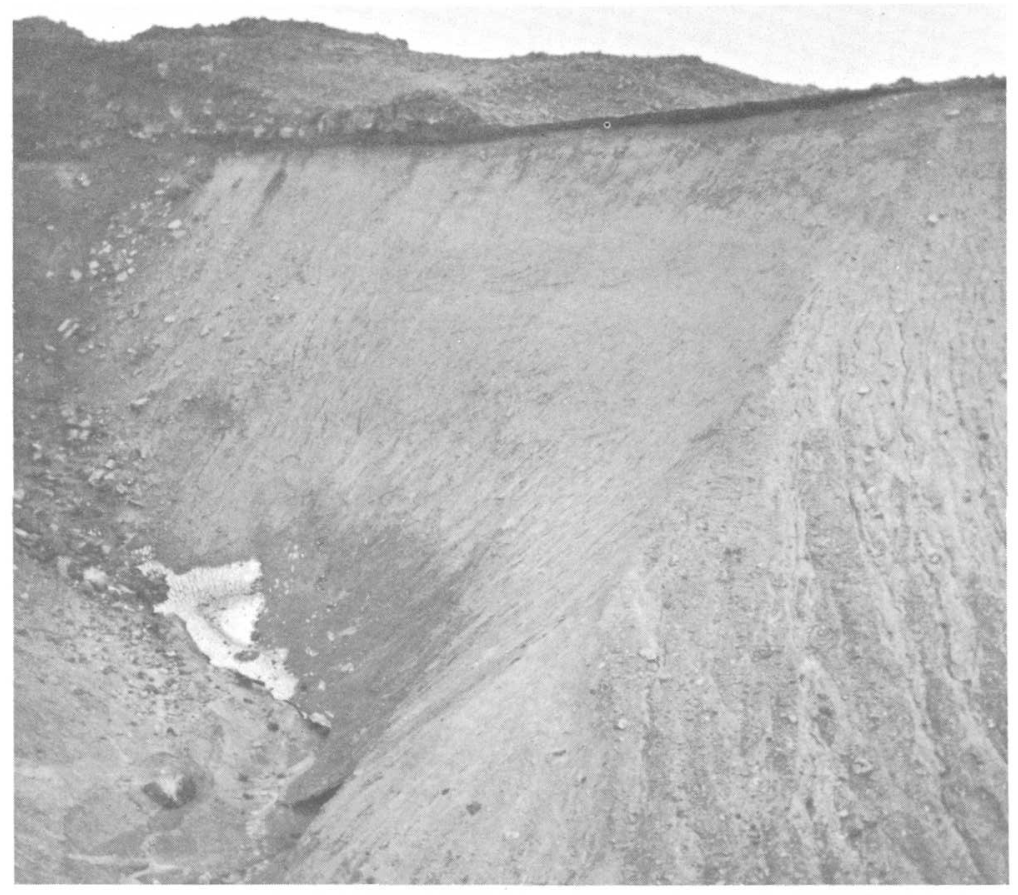

A. GULly NEAR THREEQUARTER CONE

Gully is about 2 miles south of Threequarter Cone. Shows 150 feet of dacitic pumice overlain by 2 feet of basaltic scoriaceous ash. In background, flow erupted from Mount Cerberus rests on the even surface of the ash.

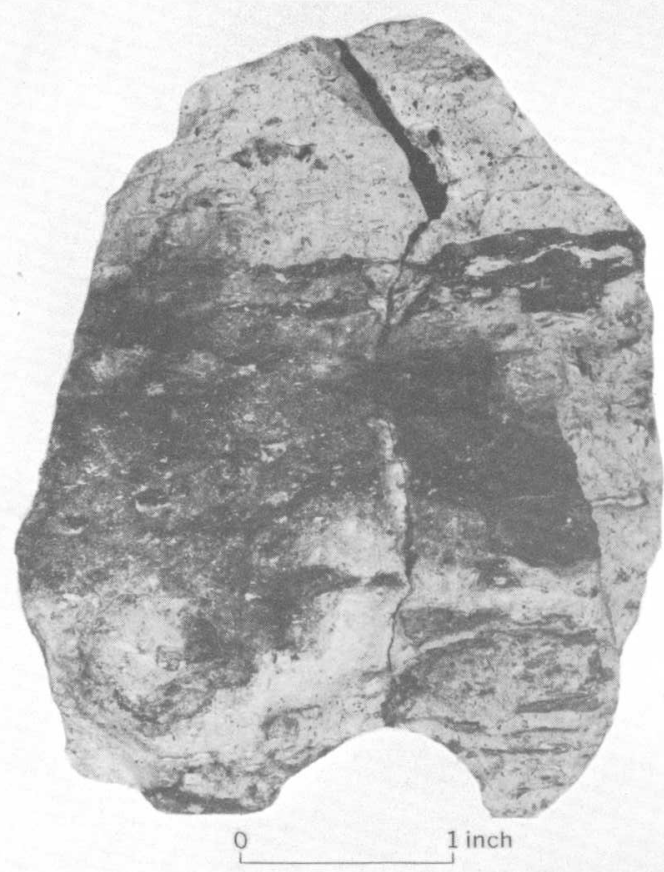

B. DACITIC PUMICE

Specimen shows the included fragments of old rock from walls of magna chamber. Some fragments are softened, flattened, and drawnout; others are quite rigid. Photograph by N. E. Shupe. 


\section{PUMICE ERUPTION AND THE FORMATION OF THE CALDERA}

The most cataclysmic events in the history of Semisopochnoi Island were the eruption of tremendous volumes of light-gray rather fine-grained dacitic pumice, followed by the subsidence of the great central caldera. The dacitic pumice is well exposed in a gully about 2 miles south of Threequarter Cone. It is overlain by 2 feet of basaltic cinders, including scoriae as much as 10 inches in diameter, which in turn is irregularly capped by several flows from Mount Cerberus. The total thickness of the dacitic pumice here exposed is 150 feet, but the base is hidden. The pumice seems (pl. 63A) almost structureless and uniform from top to lowest exposed part, but certain minor differences can be found on examination. It is slightly indurated, having about the same resistence to a pick as a stiff till. The largest fragments of pumice seen here are about 6 inches in diameter and contain irregular cavities; they are commonest in the highest part of the pumice bed, which also contains some pumice fragments with elongate streaks and strands of dark-gray material (pl. 63B). There are also some smaller fragments of dark obsidian, which grade, by increase in amount of elongate vesicles, into a light-gray pumice with silky texture. The uppermost 6 feet of the deposit includes many accidental fragments, as much as 3 feet wide, of medium-gray phenocryst-rich basaltic andesite, typical of the material making up the old Pochnoi cone.

Some of the pale-gray $(N 7)$ pumice is inflated to the point where some fragments will float on water at least 16 hours. Undoubtedly more would do so if the vesicles were isolated. Most of the material is sand to silt in size, and some will remain in suspension in water for at least 16 hours. As shown by the transition in character, the pumice and the obsidian are very similar; both consist of glass, are colorless in thin section, range in refractive index from 1.512 to 1.517 , and contain sparse phenocrysts of labradorite $\left(\mathrm{An}_{53}\right)$, augite, and brownish-green hornblende wholly free from any resorption border. A little magnetite and some clear needles of apatite are present in specimens from some localities. The index of refraction suggests (George, 1924) a silica percentage of about 65 and a probable dacitic composition. The dark streaks are largely composed of brown glass with an index of 1.524, suggesting a silica percentage of about 62 . The darker streaks are rich also in augite and plagioclase, and enclose nodules of andesite. Other inclusions contain olivine, as well as augite and plagioclase. 
It seems that a part of the superstructure of the volcano has been stoped into the magma chamber underneath, and that some of this more mafic rock of the old cone has been wholly or partly remelted and in part incorporated into the eruptible magma. Evidences of contamination are found in only a few of the fragments of pumice. This fact suggests that the erupted material contained a much smaller proportion of material assimilated from the walls of the magma chamber than Fenner (1920, p. 593-596) thought to be the case at Katmai. Apparently the tearing away and erosion of the walls of the conduit by the gas stream and the ejection of fragments of the old rock were important only toward the close of the cataclysm. The denser fragments of dacitic glass suggest that a part of the magma was chilled by contact with the atmosphere or with cold rock, an event that must have preceded the catastrophic emptying-out of the magma chamber. Perhaps relatively stiff, viscous dacitic glass was extruded as a tholoid, or dome, into the crater of the volcano, just before the eruption. The elongate tubular shape of the vesicles in the denser glass contrasts strongly with the more nearly spherical, irregular vesicles of the larger pumice fragments, and suggests viscous flow rather than the turbulent expansion of a hot, volatile-rich glass from which the pressure has been suddenly released. The presence of the green hornblende completely free from any sign of oxidation or resorption indicates that the glass could not have been exposed, for any appreciable period, to conditions of high temperature and low pressure, which have been shown by Barnes (1930) to result in oxidation of the hornblende. Kozu and his colleagues (1927) found that the oxidation of green hornblende can be completed over a narrow temperature range near $750^{\circ} \mathrm{C}$. That the temperature of the eruption must have been relatively low is shown by the lack of welding of the tuff.

\section{VOLUME AND MODE OF ERUPTION}

The total volume of material erupted will probably never be known with any degree of accuracy, as great thicknesses are now exposed by the sea cliff in some valleys, indicating that much material was carried beyond the shoreline. On land, the greatest observed thickness of the dacitic pumice is 160 feet, where it is overlain by the scoriae of Threequarter Cone. It is 140 feet thick in the wall of the caldera just south of Anvil Peak. The thickness ranges widely, however, and in many places is only 1 or o feet. In other places the pumice either was not deposited or 
has been removed by erosion. It is noticeable that the thinner deposits are in places that were topographically sheltered from the central crater of the mountain.

On the northwest shore, $31 / 2$ miles east-northeast of Tuman Point, Powers found only 2 feet of siliceous pumice, underlying 25 feet of loose basaltic ash and fine loesslike ash. About $13 / 4$ miles northwest of South Point and one-fourth mile from the sea, along the west wall of a small gully, $21 / 2$ feet of coarse yellowish-gray $(5 Y 8 / \mathbb{1})$ pumice, in rragments as much as 3 inches in size, directly overlies a 1-inch layer of pale-gray ash of medium-grained sand size, which in turn rests on the disintegrated andesitic bedrock. Along the sector of the old Pochnoi rocks to the west of this station, stripped surfaces show mo recog. nizable remnants of the dacitic ash, until the high cliff $21 / 2$ miles northwest of South Point is reached. Exposures in the face of this clifi show about 80 feet of light-colored material, presumably the dacitic ash, near the top of the cliff. Oblique aerial photographs (see pl. 64) show about 80 feet of light-colored ash near the east flank of Southwest $\mathbb{K}$ nob. What the depth is near the axis of the valley cannot be determined, but it may well be somewhat greater. The thickness in the valley to the west of Southwest IKnob is considerably less, judging from aerial photographs, perhaps because the ash on this side of the knob had traveled farther from the crater. The apparent thickness at a point on the sea cliff just south of the 1,437-foot peak is about 15 feet.

The dacitic tuff obviously was not deposited by an ash shower that fell vertically from the sky, instead it flowed down the valleys like a heavy fluid; it was, in short, a glowing-cloud deposit, though one of relatively low temperature. It is possible that some of the pumice, particularly the coarser fragments, may have been ejected at a relatively high angle from the crater, and that this more nearly vulcanian mode of projection may account for the coarser average size of the fragments in the places where the deposit is thin. Whether the coarser fragments represent any particular phase of the eruption it is now difficult to say, but in the thick exposure of ash in the valley northeast of Southwest IKnob the coarse fragments of pumice are commoner near the top.

An estimate of the volume of dacitic ash, between the caldera walls and the present shoreline of the island, made by counting 1,000-yard squares and assuming that the thickness diminishes about 20 feet in each thousand yards, indicates that the total 
volume has an order of magnitude of $1.5 \times 10^{6}$ cubic yards. As the present area of the caldera is about $51.5 \times 10^{6}$ square yards, the ash, not allowing for the considerable degree of porosity, ${ }^{2}$ would fill the caldera to a height of only 26 yards, or about 75 feet. Even the most generous estimates of material dispersed beyond the present shores of the island will not account for enough material to come near filling the great caldera in its primal state, for it occupies the heart of a mountain that once must have risen to a height of 5,000 feet or more.

This problem is the same as that faced by Williams (1941) at Crater Lake, by Byers and others $(1947$, p. 36) at Umnak Island, by Simons and Mathewson (1955, p. 36) at Great Sitkin Island, and by Coats $(1956$, p. 77) at Kanaga Island. In many parts of the world then, the volumes of material extravasated by calderaforming eruptions are inadequate to account for the void into which the superstructure of the volcano has collapsed, and this fact must be something more than coincidental. Williams (1942, p. 105) has suggested that this material may be disposed of by intrusion into radial fractures opening at the time of maximum magmatic pressure, which as he has pointed out, is precisely the moment preceding the first explosion. It seems to me, however, that there are two objections to this hypothesis. There is insufficient surface extrusion dating from the time of caldera formation to account for any sizeable fraction of the surplus hot, gas-charged silicic magma that must have been in the magma chamber before the formation of the caldera. It is scarcely conceivable that doming and stretching of the rock of the magma chamber adequate to produce fissures with so large a total volume (10.5 cubic miles, in the case of Crater Lake) should have produced only blind fissures, none of which reached the surface. This objection becomes especially telling when the mechanics of the doming and stretching are considered; for the steeply dipping radial cracks formed by stretching the solid cover of the magmatic blister would tend to be widest at the surface and grow narrower downwards-surely an unfavorable circumstance for the production of "headed dikes" that terminate without reaching the surface.

Two clues to a much more feasible method of disposing of the excess magma may be found. One of these is afforded by studies of ground tilt at Kilauea, which have shown that the surface

\footnotetext{
2 The bulk specific gravity as measured on an 1,128-gram sample of the ash, including accidental fragments, and after excavation and transportation, was 1.8. The probable specific gravity before excavation is 1.5. I am indebted to W. G. Schlecht for assistance in making this measurement.
} 


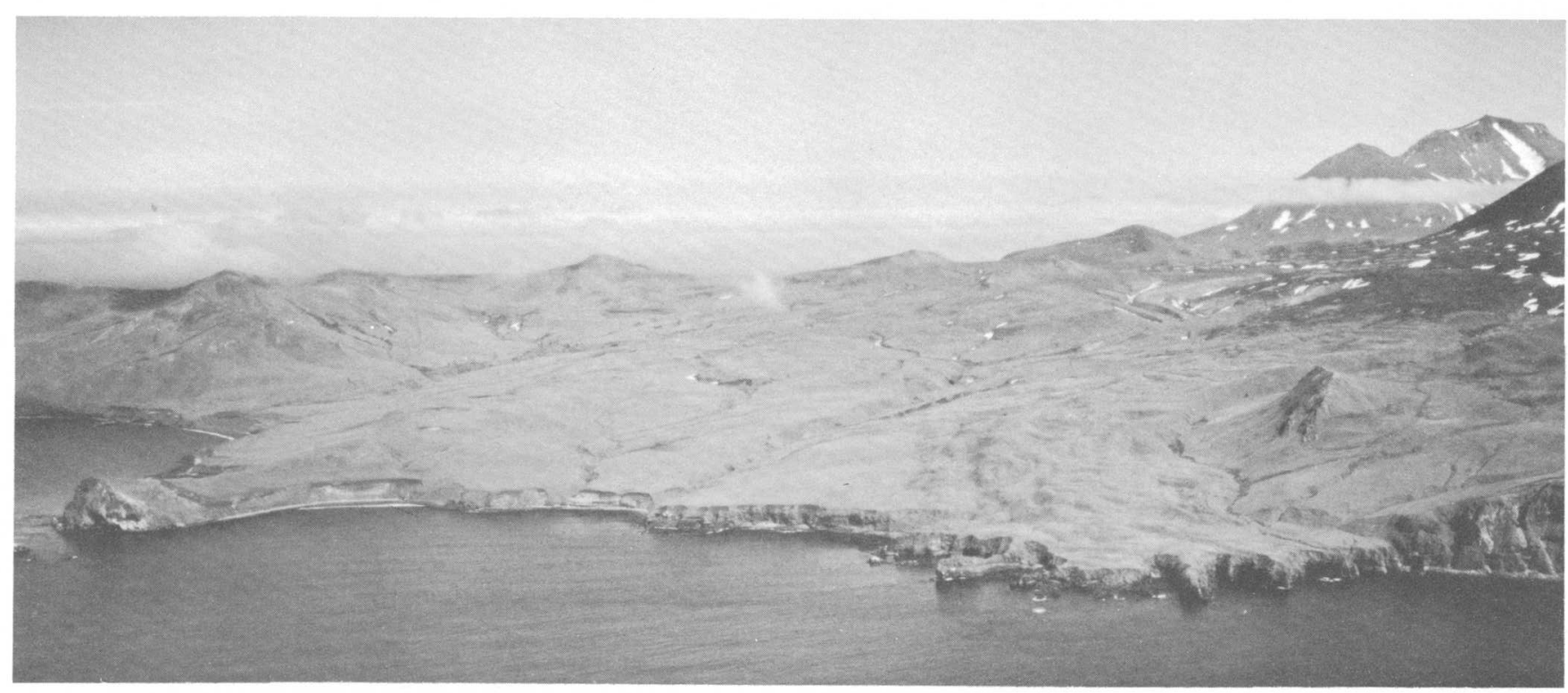

AERIAL VIEW OF THE SOUTHWEST COAST OF SEMISOPOCHNOI ISLAND Shows the irregular surface of a Recent flow (right) that is somewhat modified by ash deposits. Sea cliffs at left are light-colored dacitic ash overlain by Recent basaltic ash.
Anvil Peak is in background. Photograph by U.S. Navy. 


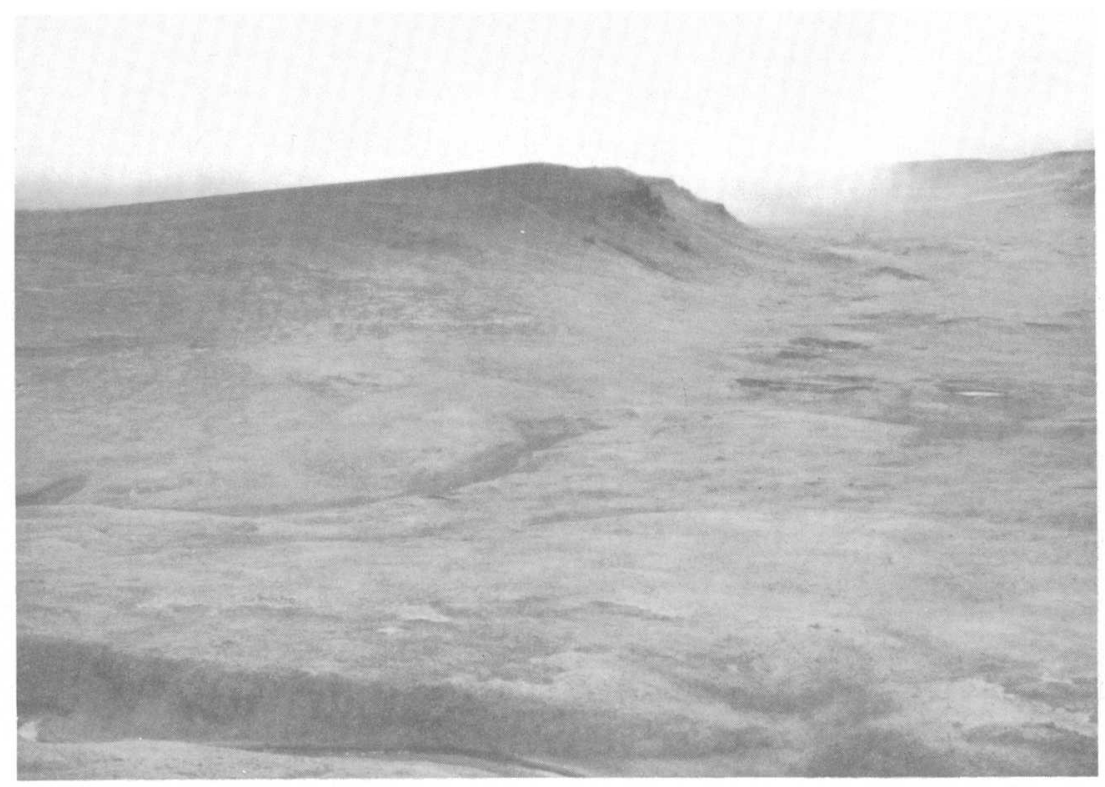

VIEW LOOKING SOUTHWARD FROM THE WEST SIDE OF RAGGED TOP

Shows the gentle dip slope (left) and steep scarp face (right) of the 705 -foot remnant of the early postcaldera cone. 
here is affected by the rise of magma at Mauna Loa, and thus presumably by magmatic tension in the Mauna Loa magma chamber. I would infer a magma chamber that is not steep roofed, but has a considerable lateral extension; in other words it is blisterlike, or laccolithic in shape, in the Gilbertian sense. Given such a shape, space for the excess magmatic volume will much more readily be made by sheetlike or laccolithic intrusion than by diking of the superficial crust. As Hunt (1942, p. 198) has shown for the Henry Mountains, a considerable degree of stretching of the superjacent cover above an intrusive mass is possible. Here also, although dikes are present, they are negligible in volume by comparison with the laccoliths, which depart widely from the classic shape deduced by Gilbert. ${ }^{3}$

The most telling objection to this explanation of the possible fate of the missing magmatic material is the lack of physiographic evidence of the doming that it would involve. If the injection were relatively sheetlike, little tilting of the superjacent cover would be expected; but if any considerable quantity of the missing magmatic material has been stowed away beyond the line of the caldera walls, there should be evidences of uplift, in the form of marine terraces about the shores of Semisopochnoi. If such terraces were ever present, they have been obscured by subsequent rise of the sea level, or isostatic sinking of the island in response to the added weight of the volcanic cone on the earth's crust.

A still greater difficulty is that the necessary intrusion can be accomplished only by a magma under considerable pressure, and the development of this pressure before the formation of the caldera hardly seems compatible with the creation of a substantial void into which the superstructure of the mountain can collapse. It would seem probable that the intrusion could be accomplished only by a magma in which the pressures at a given depth were higher than at any previous time. But then it becomes difficult to see why the caldera-forming eruption should take place just after the intrusions, which have presumably gotten rid not only of the surplus of material, but also of the excess pressure.

Another possibility to which relatively little attention has been given is that a considerable degree of vesiculation had already taken place in the magma over a long period before eruption, so that a larger part of the bulk volume of the erupted pumice may

\footnotetext{
3 G. A. Macdonald (oral communication, 1956) has pointed out that there is no direct evidence, in older dissected Hawaiian volcanoes, for a magma chamber of this shape.
} 
be credited to the cavity into which the mountain has collapsed. Williams $(1942$, p. 98) has suggested the possibility that there was some degree of vesicularity in the magma before eruption; but even if the volume of the vesicles in the pumice is included the calculated volume of the erupted material is less than the volume of the cavity. It seems certain thet much of the material must have been disposed of elsewhere, either by widespread sheetlike intrusions, or; in the case of Semisopochnoi, by flows of lava into the ocean.

Precise dating of the eruption of the dacitic pumice is difficult. The physiographic evidence of the truncated glacial valleys, now partly filled with ash, indicates that the caldera was formed after the latest glaciation. Glacial striae found on the saddle in the caldera wall north of the west end of Fenner Lake also indicates that caldera collapse was preceded by some glacial erosion. One outcrop (plate $62 B$ ) indicates that the glacial ice here moved northward nearly horizontally from left to right. This outcrop is about 60 feet higher than the axis of the valley, and a few hundred feet north of the edge of the caldera wall. There must have been a glacial gathering ground of some extent on the high ground that once occupied the place of the caldera.

\section{EARIY POSTCAIDERA ERUPTIONS}

The dating of the various volcanic materials erupted since the caldera collapse cannot be precise, because in many places the earlier materials are completely buried beneath the later ones, and the products of the different vents cannot always be distinguished from one another. Dating must depend therefore on the degree of destruction or dissection, which is influenced not only by the nature of the material and the differing tectonic and erosional accidents that have befallen it but also by the dates of cessation of eruptive activity, rather than of its commencement.

Of all the postcaldera structures, the one that has been most nearly destroyed is the one represented by a remnant that lies west of Ragged Top and north of Sugarloaf. The highest remaining part of this cone reaches an altitude of 705 feet. As shown in plate 65 , the upper surface is a dip slope, slightly modified, and declining eastward. Some of the material erupted by this cone extends down the present valley of Fenner Creek almost to the seashore, and the constructional upper surfaces, though separated by later alluvium and lava flows, can readily be connected by projection across the intervening gaps. 
The gradient of the surface averages about 5 percent, but is about 2 percent near the mouth of the valley, where the upper surface, close to the present shoreline, is 160 to 200 feet above sea level. Such a gradient, projected, would bring the upper surface down to the present sea level at a distance of 8,000 to 10,000 feet beyond the present shoreline. If the rate of removal of the material by marine erosion was as rapid as the fragmental character of the material would suggest, it does not necessarily follow that the original upper surface was ever tangential to the surface of the sea, or that a primary constructional slope extended out to sea anything like the distance suggested by these computations. The gentle dip slope is terminated abruptly on the west by a low but steep scarp. At the base of the scarp is a constructional surface of lava flows and detrital material that slopes gently northward from Mount Cerberus. The origin of the scarp is not certain, but its orientation parallel with the caldera rim, its straightness, and its lack of dissection, suggest that it is a fault scarp, caused by renewed subsidence along faults within the original caldera-collapse faults, which lie nearly a mile farther south, and roughly parallel to them.

The material making up the cone is almost wholly pyroclastic. Just east of the scarp the material is largely tuff-breccia that contains angular fragments of medium-gray olivine basalt. A few thin flows of basalt are also exposed near the base of the scarp. On the south side of the valley of Fenner Creek at a point about a mile from the coast, the material may be better described as brecciaceous tuff, containing a few angular, compact to scoriaceous basaltic fragments as much as 8 inches in diameter, though more than 5 percent of the fragments are less than $1 \frac{1}{4}$ inches in diameter. Exposures are sparse, but at least one of the beds is as much as 20 feet thick. Elsewhere along the valley walls the material ranges from tuff-breccia to coarse duncolored tuff.

\section{RECENT CONES}

Three Recent cones are distinguished on the map, together with the lava flows erupted from each: Mount Cerberus and Lakeshore Cone (pl. 66) within the caldera, and Sugarloaf Peak, which lies outside the caldera near the southern point of the island. There is not enough evidence to warrant any definite statement as to which is the oldest of these three. It is quite possible that renewed eruptions may take place at any of them. 
The name Mount Cerberus has been given to a compound composite volcano, which has three summits of nearly equal height, and which occupies most of the southern part of the old caldera. The three craters lie at the apices of a scalene triangle. They are not of equal size. The crater on the easternmost of the three peaks is smaller than the other two, and has to the northwest a large platform of irregular surface apparently built in a period of mild eruption during which the vent was shifting position slightly. About a mile to the east of the eastermmost major summit is a small cone, now partly destroyed, that attains an altitude of about 860 feet.

Six lava flows from Cerberus have been distinguished on the map, and also an area underlain by a number of lava flows that were not mapped separately. The distinction between the several flows rests mainly on the basis of age, and the principal criteria of age are the relative degrees to which the flows are buried with ash and covered with vegetation. Obviously these criteria must be used with caution, because the amount of ash on top of a flow depends not only on its age, but also on its position with respect to the principal sources of ash, and on the unknown wind directions prevailing at the time of the ash eruptions; the amount of vegetation, also, depends on the amount of ash, and on the altitude as well. These two criteria are fairly reliable, however, if used in discriminating between adjacent or nearly adjacent flows.

The numbering used on plate 59 reflects an endeavor to assign relative ages on the basis discussed above, the lowest number being assigned to the earliest flow. What is regarded as the youngest flow from Cerberus is one about 2,000 feet long, which was emitted near the base of the north side of the western cone. It is visible in the center of plate 66 as a small dark spot near the base of the cone. A somewhat older flow, about $21 / 2$ miles long, was emitted from a vent at an altitude of about 1,120 feet on the slopes of the easternmost cone. For most of its length it flowed at the base of the caldera wall, spreading out to a width of half a mile on the undissected detrital surface at the base of the cone but narrowing to a width of less than 300 feet where it emptied through a steep subsequent valley separating two remuants of the early postcaldera cone. Just below the narrows it entered the valley of Fenner Creek, where it spread upstream for a few hundred yards and downstream for about 0.8 mile. In the lower part of its course two separate pulses of ex- 


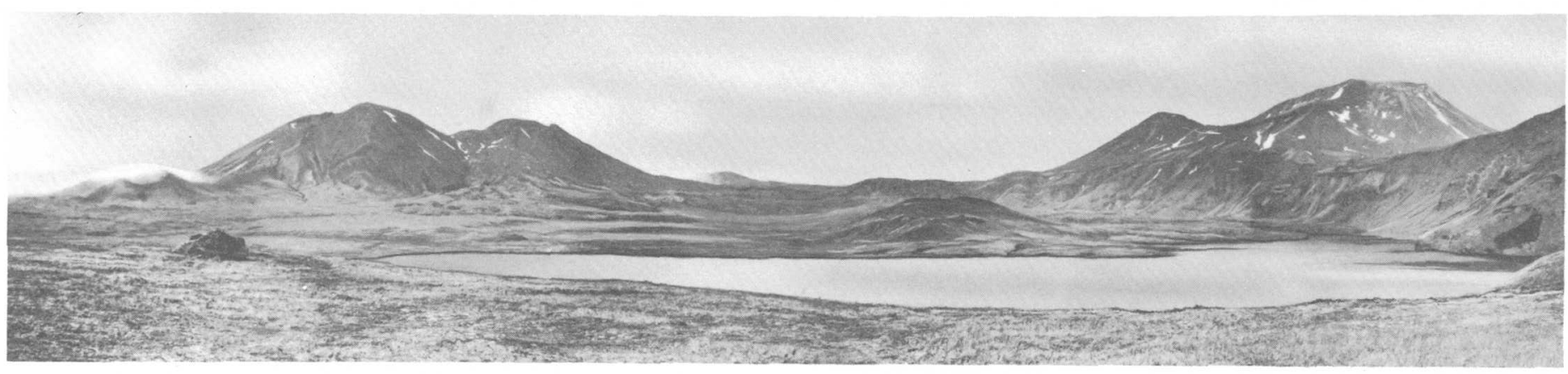

PANORAMA OF MOUNT CERBERUS FROM THE NORTH AND NORTHEAST

On the right is Lakeshore Cone lying near the shores of Fenner Lake; on the extreme right is Anvil Peak and the caldera walls. 


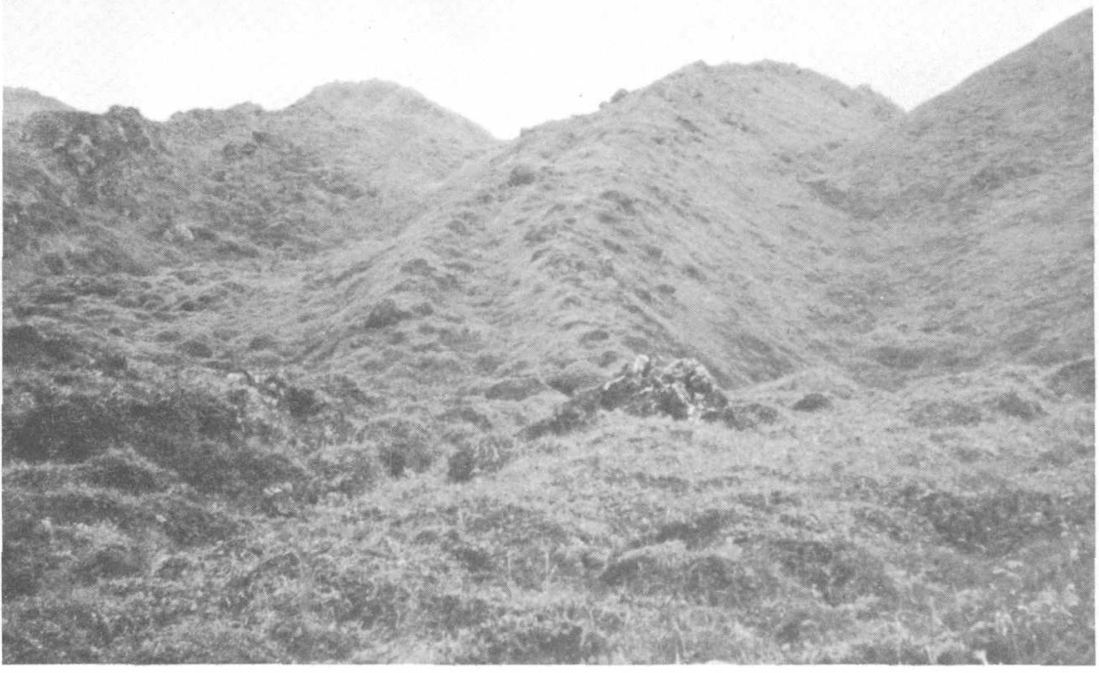

A. LAVA FLOW FROM MOUNT CERBERUS

View is up the west margin of one of the latest flows from Mount Cerberus. Double levees formed in a constriction where block lava poured down a steep valley floor, leaving the central part of the flow lower than the levee margins.

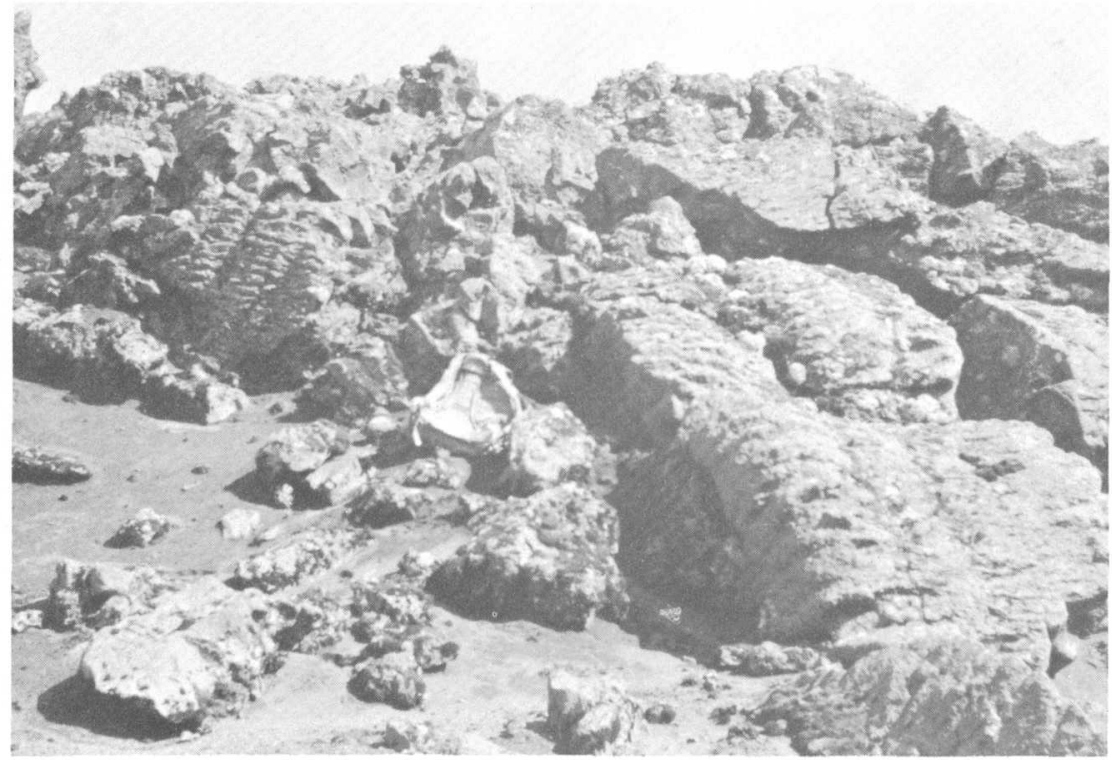

\section{B. LAVA TOES}

Extruded from the margin of a late lava flow from Mount Cerberus. 
trusion can be recognized, the later less powerful than the first, as is shown by the smaller extent of the later part of the flow and the presence of a double set of levees at the narrows, where the middle part of the flow is now notably lower than the double marginal levee (pl. 67A). This phenomenon is a physiographic expression of the continuation, after extrusion has stopped, or nearly stopped, of movement in the lava already extruded, causing the central, still fluid part of the flow to drain out, leaving the already solid marginal portions standing above the center. If an early interruption of the supply is followed by a later renewal, but at a lower rate, the second pulse will form an inner set of bilateral marginal levees, within an outer set. Each set of levees consists of two, one on each margin of the flow.

Many of the older flows on the northern flanks of Cerberus have been almost completely buried beneath the loose detrital material washed from the flanks of the cone. Presumably many other flows are completely buried. The flows on the south flank appear to be somewhat older than those to the north. About a mile northwest of South Point the later flows evidently poured over sea cliffs about 180 feet high. Veneering of clifis of this height appears to be unusual in the Recent lava flows of Semisopochnoi, as compared for instance with those of Hawaii (Sterns and Macdonald, 1946, p. 69).

An interesting demonstration of the low strength of the hot solid lava is afforded by the chatter-marked lava toes shown in plate $67 B$. These structures, which range in width from 1 to 5 feet, and in thickness from a few inches up to about $11 / 2$ feet, show a crude longitudinal grooving, and, on a smaller scale, transverse circumferential grooves, at nearly uniform intervals corresponding to the regularly spaced cracks on the stretched side of a thick metal turning. Apparently the lava toes were extruded from cracks in the front of the flow when the lava had about the consistency of a very stiff paste, and the stretching of the convex side produced the transverse markings shown in the view. Genetically, these structures are the equivalent, for block lava, of the toes described by Jaggar (1931, p. 1-3) in a pahoehoe flow. Similar tongues of lava, formed on the front of the 1948 lava flow from Hekla, in Iceland, have been described by Einarsson (1949, p. 31) under the name of "toothpaste tongues." Einarsson observed the tongues in the process of formation and found that the motion is extremely slow, so that it can be detected only by comparing observations made at intervals of several hours. He believed that the tongues contained fluid lava 
"which is crystallizing outwardly, not because of cooling but because of shearing movement."

The toothpaste tongues or lava toes described above were observed at the front of a flow opposite the north point of the southerly sector remnant of the old volcano, 1.2 miles southsouthwest of the summit of the southwestern peak of Mount Cerberus. A few feet away what appears to be a rootless scoria mound rises from a cinder-floored depression to a height of about 30 feet. It is composed principally of black and red scoriae, some of them as much as 5 feet across. This mound may have been produced by the advance of an older, now buried flow across a small body of water or water-soaked alluvium that then lay at the base of the old caldera scarp. It is possible, however, that it was produced by magma ascending along the marginal fault of the caldera; the presence of agglutinate ( $\mathrm{pl} .68 \mathrm{~A}$ ) suggests a rather high temperature for the ejecta, and may be taken as evidence in favor of such an origin.

Most of the lava flows from Cerberus appear to have been emitted either near the base of the cones or from the flanks at altitudes of not more than 1,600 feet. They consist of porphyritic basalt, which contains hypersthene accompanied in places by olivine. The fragmental material making up the cones consists mostly of fragments less than 1 foot in diameter; about 95 percent of the material is made up of angular pieces of accessory lithic basalt, and about 5 percent of the material is highly scoriaceous black to dark-gray essential lapilli. Near the rim of the southeastern crater, a few partly solfatarized blocks as much as 5 feet across give evidence of minor phreatic explosions that have dislodged altered material from the crater floors.

\section{LAKESHORE CONE}

Lakeshore Cone is a small scoria mound, with a maximum altitude of 585 feet, on the western shore of Fenner Lake. From the northwest side of its base two flows have escaped. The younger one has crossed the older one and the irregularities of its front now make minor coves and peninsulas near the northern extremity of Fenner Lake. The cone was not examined at close range and nothing is known of the composition of its lava flows.

\section{SUGARLOAF PEAK}

To the mariner, one of the most conspicuous landmarks on the island of Semisopochnoi is the cone called Sugarloaf Peak, 


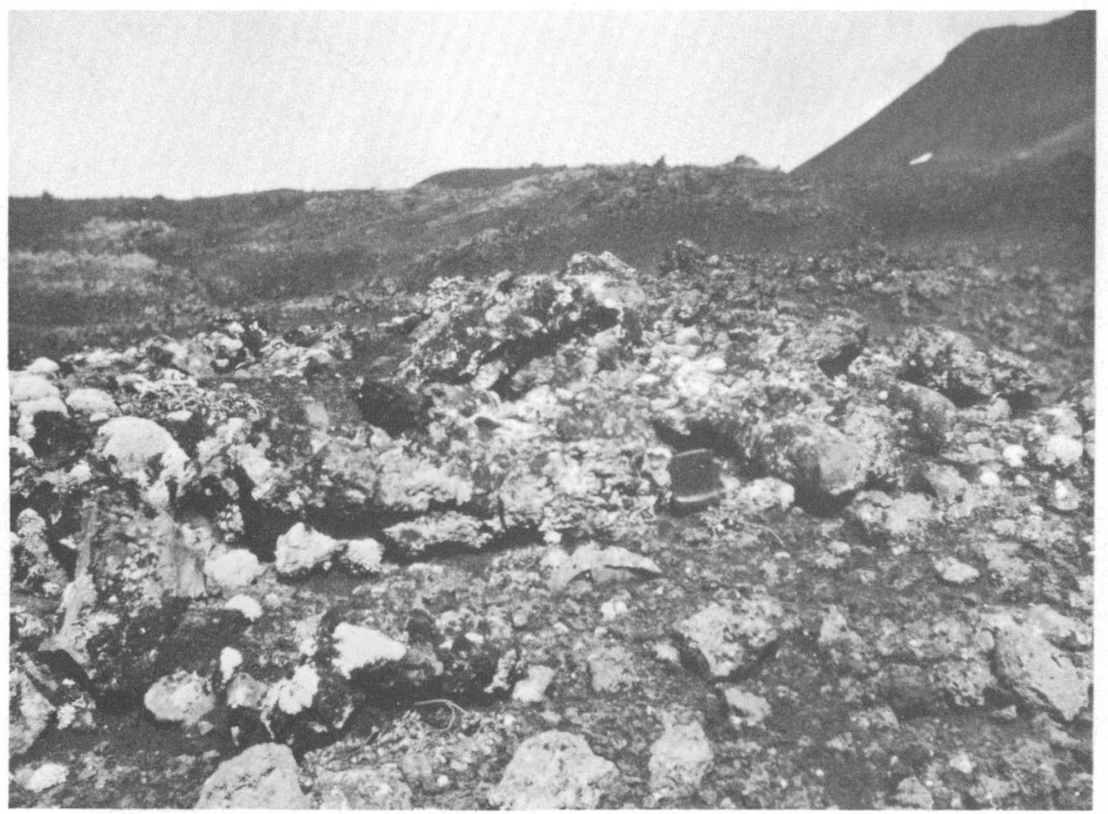

\section{A. AGGLUTINATE}

On top of small cone at south base of Mount Cerberus and near foot of inner scarp of the south sector of the shield volcano. Camera case gives scale.

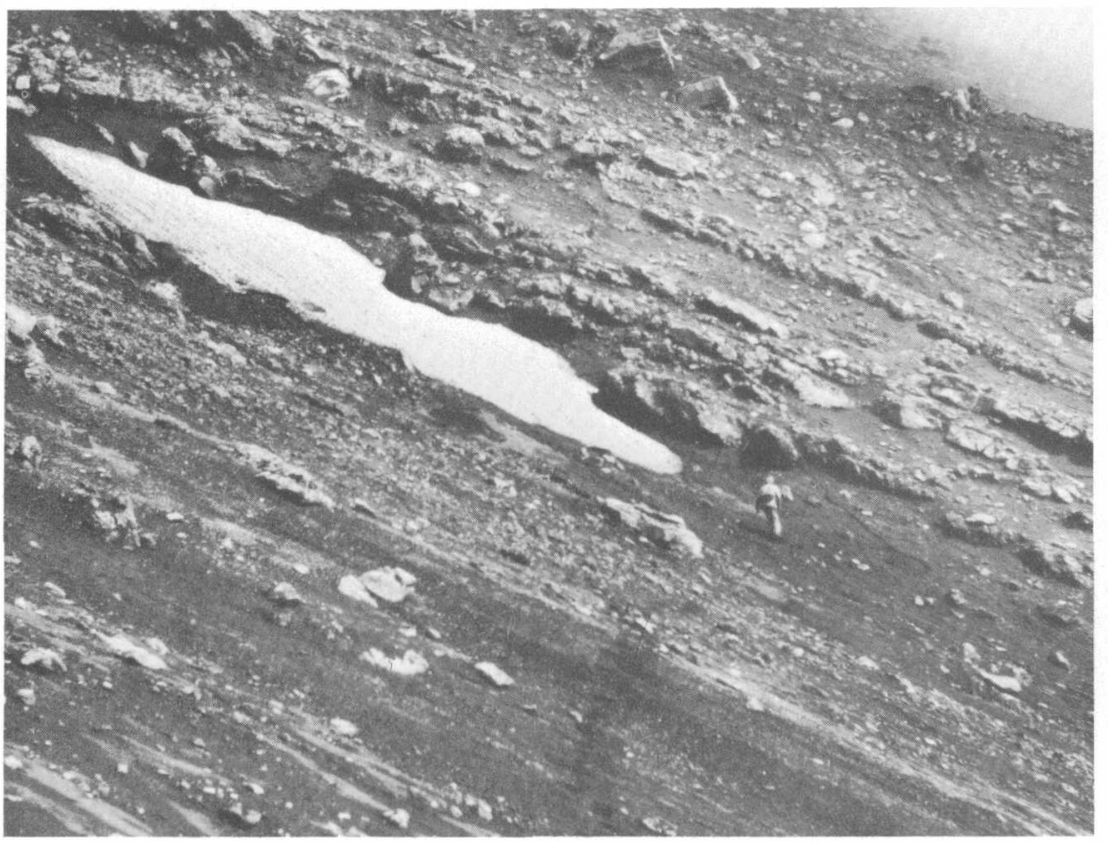

B. VIEW ON SOUTH SIDE OF SUGARLOAF PEAK

Shows thin lava flows and beds of pyroclastic material. 
which is 2,808 feet high. This is the most southerly of the higher cones of the island, and it still retains its original form, though nothing remains of the old crater but a rather shallow saucer, opening toward the northeast, with a cliffy escarpment a few feet high on some sides, suggesting that the whole surface of the mountain has been lowered somewhat by erosion. Sugarloaf is chiefly composed of loose materials, though thin lava flows, as much as 6 feet thick, make up a respectable proportion of its bulk. Many of the larger fragments seen in plate $68 B$ are fragments of these flows, detached by gravity when the flow became too viscous to move farther as a fluid.

On the southern flank of the main cone is a double parasitic cone. The higher part, 1,620 feet high, has a double crater; the more southerly and lower crater has on the south a narrow rim that rises 10 feet above the bottom of the crater, and 20 feet, in a steep cliff, above the gravity slope of cinders on the outer face of the cone. It is evident that gravity, wash, and the effects of the strong winds have lowered the whole surface of the cone about 30 feet since the latest eruption. Yet some traces of volcanic heat still remain, for lukewarm steam escapes feebly from the interstices of a bed of reddened tuff-breccia and agglutinate cakes at the rim separating the two compartments of the double crater. The tips of the projecting filaments, wisps, and mammillae of glass along the steam-producing fissure are coated with opaline silica, which does not extend into the less accessible crevices of the fragments. It appears that the steam has transported and deposited the silica to form the opaline coating.

About 2,000 feet west of the double crater, and forming the other part of the parasitic cone, is a half-cone of scoriae about 1,050 feet high. One of the most recent flows escaped from the southern end of the gap between the two structures; it apparently was emitted at a steep tumulus, made up of broken fragments of the flow crust 3 or 4 feet thick standing at steep angles. About 90 percent of the 1,050-foot cone is composed of angular fragments of basalt, the remainder being scoriaceous lapilli. A few larger blocks, about 10 percent of which are compact and the rest scoriaceous, were also noted. Some of these blocks are breadcrusted, suggesting reheating, or disruption of a not quite solid lava. A few very small flow tongues, about 1 foot thick and 4 feet wide, are exposed on the outside of the cone. The faint, nearly horizontal circumferential banding seen on some photographs of the cone is due to the fact that the erosional surface is slightly steeper than the original surface of the cone. 
The lava flows of Sugarloaf and its parasite, including the pyroclastic fragments, are olivine basalt and picritic olivine basalt, apparently without hypersthene. In lacking this mineral they differ notably from those of Mount Cerberus which, with one doubtful exception, uniformly carry that mineral. As the two cones were active at nearly the same time, it may be that they tap different magma chambers, or different parts of the same chamber.

\section{UNCONSOLIDATED DEPOSITS}

\section{ALLUVIUM, ELUVIUM, AND TALUS}

The pyroclastic deposits of the various volcanic cones, particularly those consisting largely of fine ash, are readily set in motion when saturated with water, and move down the steeper slopes to form wide aprons of eluvium, deposited in part by mass movement of saturated material, in part by slope wash and stream transport. Most of the deposits thus formed have not been mapped, as they have not obscured the underlying contacts; but extensive aprons have been formed on both sides of the lower part of Fenner Creek valley. The lower margins of these rest upon the terraces of tuff-breccia from the early postcaldera cone, which have protected them from removal by Fenner Creek.

Much larger bodies of alluvial material have formed in the bottoms of the wider stream valleys, particularly in those to the north of Ragged Top, and south of Tuman Head, and in that of Fenner Creek. Much of the material of the alluvium is reworked ash, some of it from the dacitic pumice eruption and some of it from the later basaltic eruptions. The cross profiles of these valleys in their alluviated reaches suggest that the bedrock floors lie some distance below present sea level.

\section{SAND DUNES}

Where the wider flat-floored valleys reach the sea the wind has erected a single or multiple dune ridge, parallel to the shoreline. None of these ridges is more than 40 feet high. Whether a ridge is stationary or is migrating landward or seaward depends chiefly on the ratio of the supply of material by the local stream to the effectiveness of marine erosion in removing it. Where the rate of supply exceeds the rate of removal, the shoreline tends to advance seaward, and the drier material exposed at low tide is available to the wind for the building up of the dune ridge. 
Where the supply is insufficient, wave erosion removes the ridge and attacks the alluvium on the landward side of the ridge, unless the rate of eolian transport is greater than the rate of marine erosion. The presence of dune ridges at the mouths of all the alluviated valleys suggests that the supply of material that filled the valleys has not yet failed. As the beach progrades beyond the protection of the adjacent headlands, a kind of equilibrium is probably established, governed chiefly by the variation in effectiveness of wave attack with variation in exposure.

\section{GEOLOGIC HISTORY}

The oldest episode in the history of Semisopochnoi of which there is any record begins with the eruption of a series of basaltic tuff-breccia, followed by flows of mafic lava, building up a volcano having nearly the dimensions of the present island and perhaps as much as 3,000 feet high. Upon the broad low dome thus erected several smaller and steeper cones of andesitic lava and pyroclastic material were superposed, including probably a central cone that raised the total height of the mountain to 5,000 or 6,000 feet. Small cones of basaltic material, consisting chiefly of cinders and bombs but including some lava flows, were constructed near the north and west coasts of the island. Much of this eruptive activity was preglacial, or at least precedes the latest glaciation, as shown by the fact that the cones produced have been dissected by glacial cirques and transected by glacial valleys. The activity was probably preceded by a time when the sea stood at least 80 feet higher than it does now, and the debris eroded from the volcanoes was locally deposited about the shores of the island as volcanic sand.

Near the end of the glacial period, the volcano produced a totally new type of product. It had apparently been quiescent for some time, and the nature of the magma had changed by differentiation during the interval, becoming much more silicic and rich in volatiles. Great volumes of hot, highly inflated, pale-gray dacitic pumice and dust were spewed out in the form of dense clouds, which rushed like torrents down the accessible valleys, overtopping low divides and filling up the lowest parts of the valleys to a depth of as much as 160 feet. The removal of the great volume of magma from the chamber by this eruption, and presumably also by unexposed intrusions extending laterally from it, prepared the way for the collapse of the top of the mountain to form an elliptical caldera, almost 5 miles in greater diameter. After a period of quiescence, eruptive activity was 
renewed, but once again basaltic tuff-breccia predominated. The new eruptions built up a low cone on the southeastern part of the caldera, from which some of the erupted material escaped as mud flows over the rim of the caldera and filled the outlet valley to an unknown depth, forming a broad gentle slope that probably extended some distance out to sea beyond the present shore. Somewhat later, several cones on the northwest side of the volcano, the largest of which may have begun to erupt before the caldera collapse, again emitted basaltic and andesitic lava. Renewed downfaulting, on faults more or less concentric with the earlier ones that bounded the caldera, destroyed part of the tuff-breccia cone in the southeastern part of the caldera, and enlarged the caldera on the north and west. Subsequent eruptions have built up one major composite basaltic cone and a minor cone within the caldera, and another major cone outside the caldera near the southeast shore of the island.

\section{HIISTORIC VOILANIC ACTIVITY}

Records of eruptions on Semisopochnoi Island are very scant. Grewingk (1850, p. 232, 281) found four reports of "smoke" in the records of early explorers, for the years $1772,1790,1792$, and 1830. Becker $(1898$, p. 17) reports that a volcano on the island was active in 1873. Since one report specified that the activity was in the interior of the island, and since the cone of $\mathbb{M}$ ount Cerberus is less dissected than that of Sugarloaf Peak, this part of the island was probably the source of the dated eruptions. It cannot be determined whether any of the lava flows distinguished on the map occurred in historic time, but one of the late flows from Cerberus may be less than 100 years old, for its vegetation is little heavier than that on flows 40 years old that may be seen at a slightly higher altitude on $\mathbb{K}$ anaga Island.

\section{$\mathbb{F U T U R \mathbb { R }} \mathbb{V} O \mathbb{L} \mathbb{C} \mathbb{N} I \mathbb{C} A \mathbb{A} T \mathbb{V} \mathbb{T} Y$}

The nature of the material erupted during the periodic minor eruptions of the smaller composite cones suggests that no greater Plinian eruption is to be expected on Semisopochnoi within the foreseeable future; this volcano has had its fling, and settled down to a humdrum existence. It is probable, however, that relatively minor infrequent eruptions may occur from time to time, contributing new lava flows and ash layers, the latter measurable in inches, to the upbuilding of the island surface. The effects on neighboring islands will be negligible. 


\section{PETROGRAPHY}

\section{POCHNOI VOLCANICS}

The most mafic of the lava flows attributed to the Pochnoi volcanics is an olivine basalt, but the series includes rocks as silicic as hypersthene andesite vitrophyre. As the analyzed rocks were collected from widely separated areas, the age relations are not completely known, and it is possible that some of the rocks may have been erupted by some of the earlier subsidiary cones, perhaps even by cones centered within the area of the present caldera depression.

A sample of olivine basalt (P49Se4) collected by Powers 11/4 miles S. $321 / 2^{\circ} \mathrm{E}$. of Northeast Point, is a porphyritic dense medium-gray $(N 5)$ slightly vesicular rock, with intergranular texture. The phenocrysts consist of plagioclase, which averages about $\mathrm{An}_{85}$ (as determined by the average index of refraction); olivine $\left(\mathrm{Fa}_{32}\right.$ as determined by the mean index of refraction), about 6 percent of the rock and ranging in length from 0.1 to 1 $\mathrm{mm}$; and sparse augite, ranging from 0.1 to $0.25 \mathrm{~mm}$. The groundmass is chiefly plagioclase, averaging $\mathrm{An}_{57}$; augite granules that are apparently pigeonitic, as shown by a $2 \mathrm{~V}$ of $35^{\circ}$; magnetite; and intersertal brown glass, charged with minute magnetite granules.

One-tenth of a mile northeast of the 1,405-foot peak $\left(120,500^{\prime}\right.$ E., $288,200^{\prime} \mathrm{N}$.) is a lava flow consisting of a medium-gray ( $N 5$ ) sparsely porphyritic and vesicular augite andesite that contains very sparse macrophenocrysts ( 1 to $3 \mathrm{~mm}$ in size) of plagioclase $\left(\mathrm{An}_{62}\right)$ and augite, which is dark green in hand specimen and very pale green in thin section. About 10 percent of the rock is microphenocrysts of plagioclase $(0.4 \mathrm{~mm}$ long), ranging in composition from $A n_{48}$ to $A n_{55}$; about 1 percent of the rock is microphenocrysts of augite. The groundmass consists of plagioclase laths, augite granules, and magnetite granules $(0.004 \mathrm{~mm})$, with interstitial quartz and orthoclase, and a little cristobalite in the vesicles.

The most silicic rock attributed to this sequence is a hypersthene dacite vitrophyre, at the 800 -foot level on the ridge $21 / 4$, miles northwest of South Point $\left(126,300^{\prime}\right.$ E., 275,100' N). The flow from which the specimen came is not well exposed, but is certainly no more than 20 feet thick, and shows intricately contorted flow parting, parallel to the layering, which is an expression of the textural range from lithic to partly glassy. The part sectioned and analyzed was from the glassier phase, and is a medium-dark-gray ( $\left.N_{4}\right)$ aphanitic dense lava, with planar struc- 
ture and waxy luster, having about 10 percent of well-oriented microphenocrysts, principally plagioclase of composition $\mathbf{A n}_{44}$, hypersthene $\left(\mathrm{En}_{80}\right)$, augite, and a trace of magnetite and pseudodichroic apatite. The groundmass consists of plagioclase, augite, and magnetite in pale glass. Vesicles are filled with cristobalite, locally replaced by tridymite.

\section{EARLY SUBSIDIARY CONES}

Specimen P49Se16 is from the next to the lowest flow exposed on Tuman Head, (104,475' E., 3,450' N.). According to Powers, who collected this specimen, the section here, is largely pyroclastic and rich in bombs and scoria. The flow from which the specimen was collected ranges in thickness from 10 to 20 feet. The rock is dense medium-gray ( $N$ 5) olivine-hypersthene basalt, with seriate texture. The plagioclase, in crystals as much as 3 $\mathrm{mm}$ in size, averages $\mathrm{An}_{77}$, judging from the average refractive index. The olivine $\left(\mathrm{Fa}_{20}\right)$ is in grains as much as one-half $\mathrm{mm}$ in diameter, and is pale yellowish green in hand specimen. The augite grains, which are as much as $1 \mathrm{~mm}$ in diameter, are yellowish green in thin section. Hypersthene prisms are much smaller, on the average. Magnetite and apatite are recognizable accessories.

Specimen 47AC98 is a medium-brownish-gray ( $5 R 5 / 1)$ dense lava, with planar vesicles, from a flow 4 feet thick on the flank of the denuded cone just south of Fenner Creek and north of Sugarloaf $\left(141,450^{\prime}\right.$ E., $280,500^{\prime}$ N.). The texture is seriate, and intersertal. The constituents are plagioclase $(0.01$ to $1 \mathrm{~mm}$ in diameter) averaging about $\mathrm{An}_{77}$, augite $(0.01$ to $0.2 \mathrm{~mm}$ in diameter), olivine $\left(\mathrm{Fa}_{30}\right.$, determined from $\left.2 \mathrm{~V}\right)$, and magnetite, with intersertal glass.

Specimen 47AC99 is olivine basalt from one of the latest flows from Ragged Top $\left(148,800^{\prime}\right.$ E., $276,000^{\prime}$ N.). The flow is about 20 feet thick, consists of medium-gray (N5) holocrystallineporphyrytic dosemic basalt, with.pilotaxitic texture. The phenocrysts consist of plagioclase ( $2 \mathrm{~mm}$ in diameter), averaging about $\mathrm{An}_{82}$, olivine $(0.5 \mathrm{~mm}$ in diameter $)$, augite $(2 \mathrm{~mm}$ in diameter) that is dark green in hand specimen, and magnetite $(0.5 \mathrm{~mm}$ in diameter). The groundmass consists of magnetite, augite, plagioclase, and interstitial orthoclase(?).

\section{LATE PLEISTOCENE VOLCANOES}

Two analyses were made of the rocks from the cones that are relatively young, but older than part of the caldera collapse. 
One of these specimens, P49Se14, (117,375 E., 10,750 N.) is from a flow, apparently derived from Anvil Peak, that predates the eruption of the dacitic tuff, according to Powers. This is a medium-brownish-gray $(5 Y R 5 / 1)$ porphyritic, slightly vesicular basaltic andesite. The phenocrysts (3 $\mathrm{mm}$ in size) include bytownite $\left(\mathrm{An}_{82}\right)$, olivine $\left(\mathrm{Fa}_{15}\right)$, and sparse augite that is green in hand specimen. The groundmass is an hyalopilitic web of plagioclase microlites, augite, and magnetite.

Another fragment (47AC116) from an agglomerate from Threequarter Cone $\left(121,700^{\prime}\right.$ E., $291,900^{\prime}$ N.) is an andesite vitrophyre. This is a dark-gray rock, aphanitic, with small tabular plagioclase phenocrysts showing a parallel arrangement. About 5 percent of the rock is plagioclase phenocrysts $(1 \mathrm{~mm}$ in diameter), having an average composition of $\mathrm{An}_{58}$. A few phenocrysts are hypersthene and olivine. The groundmass is mostly plagioclase microlites $(0.05 \mathrm{~mm}$ long), minute granules of augite(?), and magnetite dust, in brown glass, having an index of 1.546 .

\section{PUMICE ERUPTION}

Three of the samples of the dacitic pumice eruption were analyzed. One sample (47AC113), is a composite representing the full thickness of the tuff, as exposed in a gully at $122,600^{\prime} \mathrm{E}$., $284,250^{\prime} \mathrm{N}$. No section was cut as it was not certain that one section could properly represent the composite. Specimen 47AC90A is a fragment of pumice from the relatively thin layer that accumulated at $128,300^{\prime} \mathrm{E}$., $273,500^{\prime} \mathrm{N}$., in a protected sector of the old cone. This is largely a pumiceous clear glass of index 1.515, containing small shreds of dark-green glass of index 1.554. The clear glass has crystals of labradorite $\left(\mathrm{An}_{57}\right)$, hypersthene, augite, green hornblende, and apatite. Another specimen is a fragment from the pumice, exposed in the caldera wall at $130,000^{\prime} \mathrm{E}$., $297,000^{\prime} \mathrm{N}$. This fragment consists of brown glass, of index 1.534 with elongate vesicles,' sparse augite, plagioclase, and olivine. The high index of the glass and character of the minerals suggest a composition in the andesite range; the lower index of specimen $47 \mathrm{AC} 90 \mathrm{~A}$ suggests a silica percentage of about 66. It is probable that all the composite samples are contaminated dacite.

\section{RECENT CONES}

Late-central cones.-Two analyzed specimens are available from Mount Cerberus, specimen 47AC88 (130,550' E., 270,000' N.) is from one of the longer flows that reached the coast, and 
specimen $47 \mathrm{AC110}\left(131,000^{\prime} \mathrm{E}\right.$., $282,250^{\prime} \mathrm{N}$.) is from a relatively short flow, which was sampled on the southeast side of the southeast peak of Mount. Cerberus. The first is a medium-light-gray (N 6) porphyritic basaltic andesite; most of the visible phenocrysts are plagioclase, averaging $\mathrm{An}_{82}$, but there are also olivine, hypersthene, augite, and magnetite crystals. The olivine and augite are commoner and in larger crystals $(0.5 \mathrm{~mm}$ in diameter), than the hypersthene. The groundmass consists of plagioclase microlites : with augite and magnetite and a mesostasis of glass.

The other flow (47AC110) is a dark-gray $(N 3)$ dense vitrophyre, with a seriate texture. About 25 percent of the rock is plagioclase ( $1 \mathrm{~mm}$ in size), averaging about $\mathrm{An}_{45}$; the other phenocrysts are augite, sparse hypersthene $\left(\mathrm{En}_{65}\right)$ in slender needles, apatite as pseudodichroic prisms, and magnetite. The groundmass consists of plagioclase microlites, augite, and magnetite in pale-brown glass.

Late-lateral cone.-The only Fiecent cone that has grown outside the caldera is Sugarloaf and the small parasitic cone on its south flank. Two samples were analyzed.

One of these (P49Se6) was from a very recent flow on the eastern shore $\left(142,200^{\prime}\right.$ E., 269,550' N.), which Powers considered younger than the most recent eustatic bench, and which is unmantled by ash. Powers estimated the thickness at more than 20 feet, and notes that there was much copper staining. It is a dense medium-gray rock with conspicuous green augite phenocrysts. It is seriate, with an intergranular texture. The principal constituents are bytownite $\left(\mathrm{An}_{72}\right)$, augite $\left(\mathrm{Di}_{70} \mathrm{He}_{38}\right)$, and olivine $\left(\mathrm{Fa}_{35}\right)$ as much as $1 \mathrm{~mm}$ in diameter, in part forming clots of small prisms, and magnetite. The groundmass augite is pleochroic from pale brown to pale green, has an $2 \mathrm{~V}$ of $20^{\circ}$, and hence is rather pigeonitic. The augite phenocrysts also have thin pigeonitic outer zones.

Specimen $47 \mathrm{AC} 80\left(137,150^{\prime}\right.$ E., $271,850^{\prime}$ N. $)$ is from a compact block on the rim of the crater of the westernmost part of the small parasitic cone of Sugarloaf. It also is an olivine basalt, with plagioclase averaging $\mathrm{An}_{64}$, olivine $\left(\mathrm{Fa}_{30}\right)$ as much as 0.3 $\mathrm{mm}$ in diameter, augite less than $0.5 \mathrm{~mm}$ and green in hand specimen, and magnetite. The groundmass has an intergranular texture, with prisms of clinopyroxene and microlites of plagioclase $(0.02 \mathrm{~mm}$ in diameter $)$. 


\section{CHEMISTRY}

The analyses of 15 specimens from Semisopochnoi Island are shown in table 1, together with the spectrographic analyses for minor constituents, and the Niggli numbers. The rocks of Semisopochnoi differ somewhat from those of other western Aleutian volcanoes. The total range of variation in silica content is greater than in other islands. The rocks are slightly more alkalic, as indicated by the fact that the alkali-lime index is 59 , hence the province is calcalkaline (Peacock, 1931, p. 54). This compares with an index of 63 for Adak and Kanaga, 64.5 for Buldir, 65.5 for the common Japanese volcanic rocks (Tsuboi, 1934, p. 2271), and 63.8 for Katmai. On the other hand, the index for Semisopochnoi is comparable with that of the Newberry volcano (Williams, 1935, p. 297), and contrasts with calcic High Cascade volcanoes. The differences between the Newberry volcano and the High Cascade volcanoes seem to be correlatable with geographic position. No such difference can be seen here-the Semisopochnoi structure lies on the same line as the other recently active volcanoes of this area. The only structural feature of the Aleutians that seems to distinguish Semisopochnoi Island from the other islands is the occurrence of the great curving submarine feature of Petrel Bank, which extends, with a trend changing gradually from the northeastward through north to west, for a distance of about 240 miles. The geologic significance of this feature is unknown. Nor is there any difference in time-both Semisopochnoi and Kanaga have been active in Recent time.

\section{DIFFERENTIATION AT SEMISOPOCHNOI}

In the differentiation diagram (fig. 74), three separate sets of trend lines are indicated for the major constituents $\mathrm{Al}_{2} \mathrm{O}_{3}, \mathrm{FeO}$ (including $0.9 \mathrm{Fe}_{2} \mathrm{O}_{3}$ ), $\mathrm{CaO}$, and $\mathrm{MgO}$. These are indicated as Early, Late central, and Late lateral. The Early trend includes the rocks of the main cone and of minor subsidiary cones, formed before the first collapse of the caldera, and the pumice associated with the formation of the caldera. The Late-central trend includes the rocks of Anvil Peak and Threequarter Cone, which are later than the pumice eruption and probably earlier than the latest caldera collapse, and the rocks of Mount Cerberus, essentially Recent. The Late-lateral rocks are those of Sugarloaf Peak and its parasitic cone. The Early sequences are indicated by solid lines, the Late-central sequences by dashed lines, and the Late-lateral sequences by dotted lines. For $\mathrm{Na}_{2} \mathrm{O}$ and $\mathrm{K}_{2} \mathrm{O}$, a single solid line represents the trend of each constituent. The differences between 


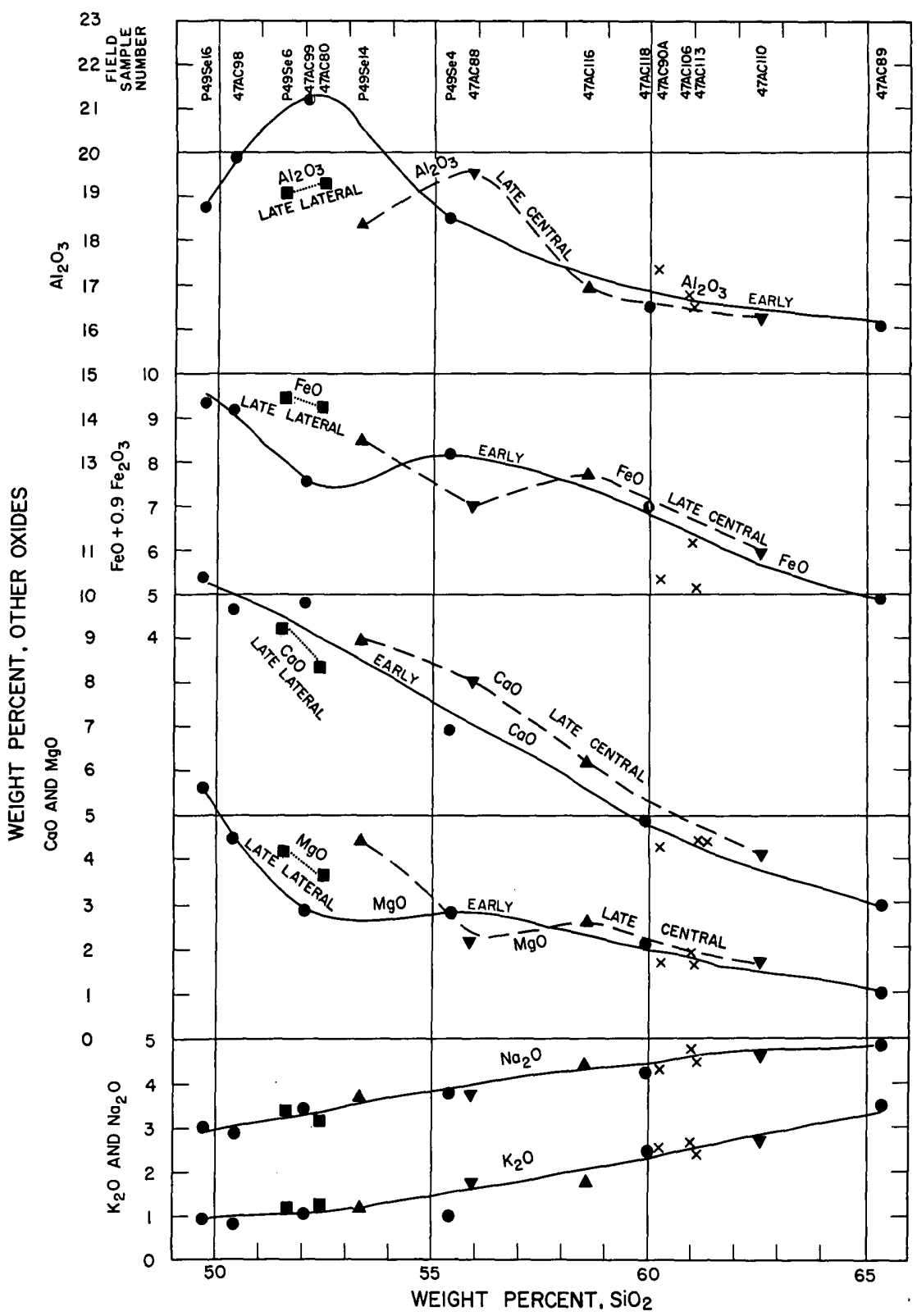

FIGURE 74.-Variation diagram for volcanic rocks from Semisopochnoi Island.

(See explanation on facing page.) 
the Early and Late trend lines are thought to be due to mixing of magmas or assimilation of material. For most constituents, the position of the Late-central lines can be explained by assuming a differentiation following a trend like that of the Early rocks, and beginning with an initial material consisting of a mixture of a primitive magma like the least silicic rock shown, with dacitic material closely resembling that erupted at the time of the formation of the caldera-in other words, a resurgence of primitive magma into the basal portion of the old magma chamber, still occupied by dacitic material, and the mixing of the two. The Late-lateral lines, comparatively short in trend, seem to be explainable as the product of hybridization of a similar primitive magma with material lying on the earlier course of magmatic evolution, at about 54 or 55 percent silica, and the evolution of this magma. This hypothesis is consistent with the idea that the evolution of the most silicic rocks has been confined to the central magma chamber, and that such rocks were available for purposes of hybridization only to magma rising in, or near the borders of, the old caldera.

A comparison of the differentiation curves for the analyzed Semisopochnoi rocks with those of Adak and Kanaga Island (Coats, 1952, p. 494) shows differences that are in part reflected by the difference in alkali-lime index. In general, it may be said that the alumina curve is higher, and declines more steeply in the Semisopochnoi rocks than in those from Adak and Kanaga. While the $\mathrm{CaO}$ line declines more steeply toward the silica-rich end, the iron, taken as $\mathrm{FeO}$, shows no significant differences. The $\mathrm{MgO}$ line is consistently lower, and falls more rapidly toward the silicic side; the $\mathrm{Na}_{2} \mathrm{O}$ and $\mathrm{K}_{2} \mathrm{O}$ lines both climb more steeply in the same direction. These trends are consistent with a dif-

Explanation for figure 74 .

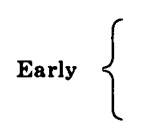

Shield volcano and subsidiary cones

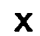

Caldera-forming pumice

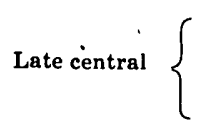

Late lateral \{

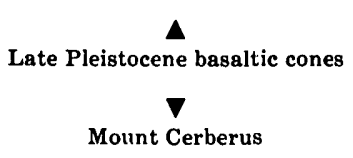

Sugarloaf Peak 
ferentiation that differs from that at Adak and Kanaga in the more effective removal of ferromagnesians, at first olivine, and later pyroxene. What causes could bring about such a trend is uncertain. Assimilation of a certain amount of aluminous sediments may have contributed to the effect.

By using the magnesia-iron oxide-alkali-metal oxide diagram that was used by Poldervaart (1949, p. 177-188), modified by combining 0.9 of the $\mathrm{Fe}_{2} \mathrm{O}_{3}$ with the $\mathrm{FeO}$, the contrasts between Semisopochnoi rocks and those from some of the other Aleutian volcanoes are easily seen (fig. 75). For comparison, the positions of the 4 points representing the averages computed by Daly (1933, p. 9-17) for basalt, andesite, dacite, and rhyolite, are plotted; also the positions representing the analyses of 5 rocks from Buldir Island. The points representing the Daly averages fall on a smooth curve that is convex toward the iron vertex, and trends toward a point on the iron-alkali side about 15 percent of the way from the alkali vertex to the iron vertex. The analyses of the Buldir rocks fall below the calcalkaline curve; those of the Semisopochnoi rocks fall somewhat above it,

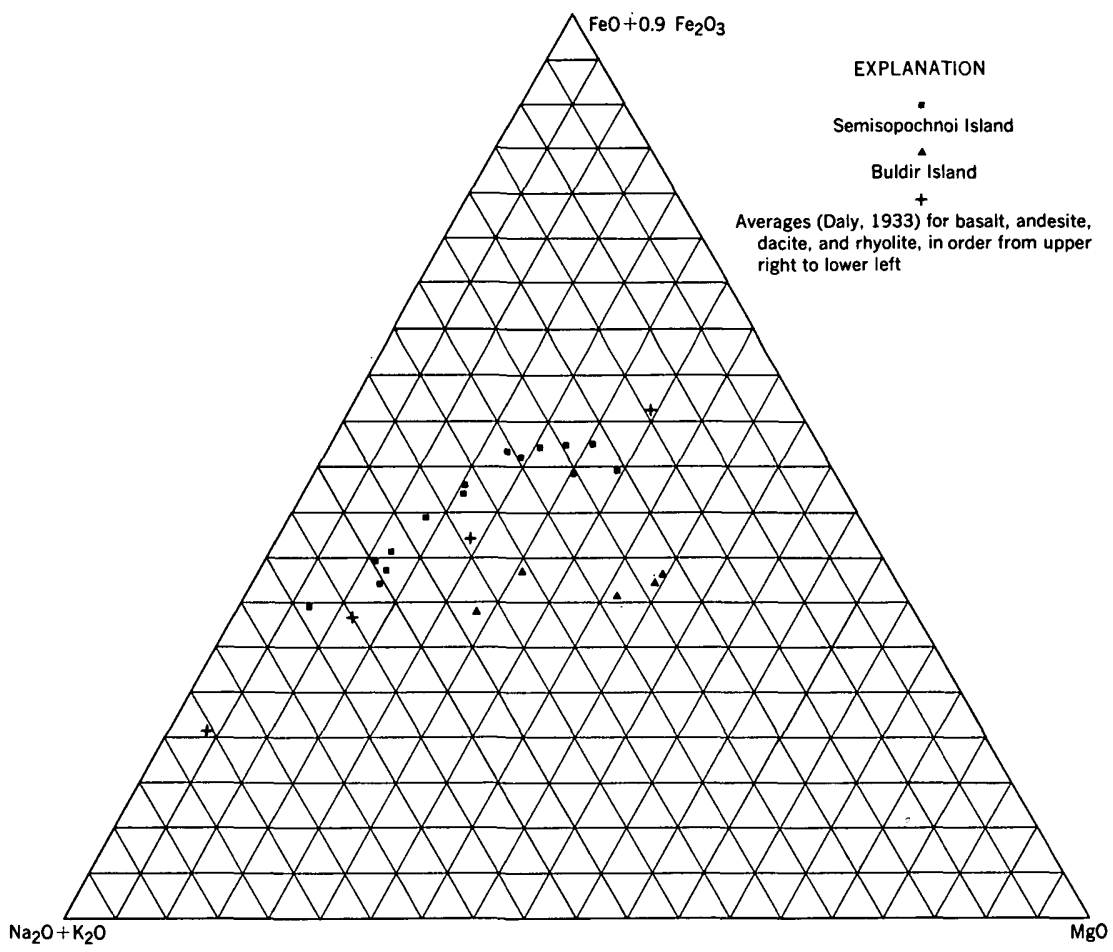

Figure 75,-Relation of magnesia $(\mathrm{MgO})$, iron (as $\mathrm{FeO}$ ), and alkalies $\left(\mathrm{Na}_{2} \mathrm{O}+\mathrm{K}_{2} \mathrm{O}\right.$ ) in volcanic rocks from Semisopochnoi Island. 
on the average. The Adak and Kanaga rocks fall on, or equally to either side of, the curve (Coats, 1952, p. 500). These relations suggest that there has been a slight degree of iron enrichment in the intermediate rocks from Semisopochnoi Island.

Bowen (1947, p. 273) has suggested that the differences reflected by these differing trends are due to the retention of volatiles, consequent upon a less pervious roof, in the mass that follows the "normal" differentiation trend, and that iron enrichment is due to substantially dry differentiation, in a mass with a thin and porous roof. The petrography of the several Aleutian Islands thus far studied is consistent with this explanation: the rocks of Adak and Kanaga commonly carry some hornblende; in those of Buldir hornblende, or pseudomorphs after hornblende, is very common, whereas not a single rock from Semisopochnoi shows hornblende, except the dacitic pumice associated with the caldera-forming eruption. On the other hand Kennedy $(1948, p$. 529-549) has shown by experiment the influence of the partial pressure of oxygen in controlling the ferrous-ferric iron ratio and hence the early appearing phases. When oxygen pressure is modest, early crystallization of magnesio-spinel removes much of the iron and conditions a crystallization that will follow the "normal trend." If partial pressure of oxygen is very low, differentiation toward an iron-rich residue will occur. None of Kennedy's experiments resulted in the production of hydroxylbearing ferromagnesians such as hornblende or biotite, that are commonly associated with the "normal" calcalkaline differentiation trend. It seems likely that the addition of water under high pressure conditions would result in the crystallization of hornblende or biotite rather than pyroxene, that the hydrogen released by the formation of hydroxyl-containing minerals would suffice to keep the partial pressure of oxygen relatively low. If the magma is extruded, or intruded under shallow cover, the hornblende or biotite can and does react with the magma to form oxyhornblende or oxybiotite, or, under some conditions, to a mass of pyroxene plus magnetite, suggesting that the hornblende is more iron rich than the pyroxene. It is also possible that the basaltic magma has been contaminated by selective solution of interstitial material, approaching granite in composition, in wallrocks and xenoliths, that has been carried into the magma along with the interstitial water (Kennedy, 1955, p. 492). Is it possible that the tectonic position of Semisopochnoi, at the intersection of the major Aleutian arc with the minor arc of the Petrel Bank, has resulted in more frequent dislocation of the 
crust, easier ascent of the magma, with less assimilation of the wallrock, to relatively higher positions in the crust, and in easier loss of volatiles, thus resulting in a magmatic evolution that is characterized by a slightly greater early enrichment in iron than in the "normal" basalt-andesite-dacite-rhyolite sequence?

Some of the differences and resemblances between the rocks of Semisopochnoi and those of other Aleutian volcanoes are illuminated by the Niggli plot of al, alk, and $\mathrm{c}+\mathrm{fm}$ (fig. 76). The dashed line in the diagram encloses the positions of points representing all analyzed rocks from Buldir, Adak, and Kanaga Islands. The much greater spread of compositions on Semisopochnoi is evident. It is also evident that the chief differences are in the direction of increasing al plus alk in the rocks in which the ratio of $\mathrm{c}$ to $\mathrm{fm}$ is low, while alk is low where the ratio of $\mathrm{c}$ to $\mathrm{fm}$ is high. The diagram of figure 76 is a double triangle, corresponding to cross sections IV and V of Niggli's system, whereas the range of ratios for $\mathrm{c}$ to $\mathrm{fm}$ in the rocks of Adak, Kanaga, and Buldir is small enough so that the parameters could be adequately represented on a single section.

\section{RARER CONSTITUENTS}

The results of spectrographic analyses of the analyzed rocks are shown on table 1, together with a list of the elements looked for by the spectrographer, but not found. In the table, a dash for a particular constituent indicates that it was not found in that determination. The limits of sensitivity of the spectrographic method used, for some of the elements shown as "not found," is as follows (K. J. Murata, written communication 1950).

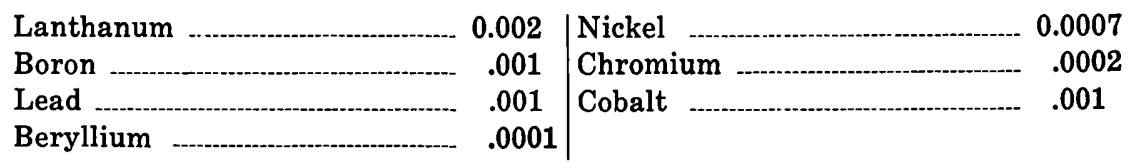

There are insufficient data from which to compute precise ratios (Coats, 1952, p. 511). In a general way, however, certain trends are evident. The ratio of cobalt to $\mathrm{MgO}$ seems to increase with increasing silica percentage, whereas the ratio of nickel to $\mathrm{MgO}$ show considerable scatter. The ratio of zirconium to silica increases with increasing silica percentage. The ratio of barium to $\mathrm{K}_{2} \mathrm{O}$, when spectrographic values are used for barium content, shows considerable scatter; if the few chemical determinations for barium are used, however, the ratio of barium to $\mathrm{K}_{2} \mathrm{O}$ is about the same as that $(0.024)$ found in the rocks of Adak and Kanaga, from which the barium was determined spectrographi- 


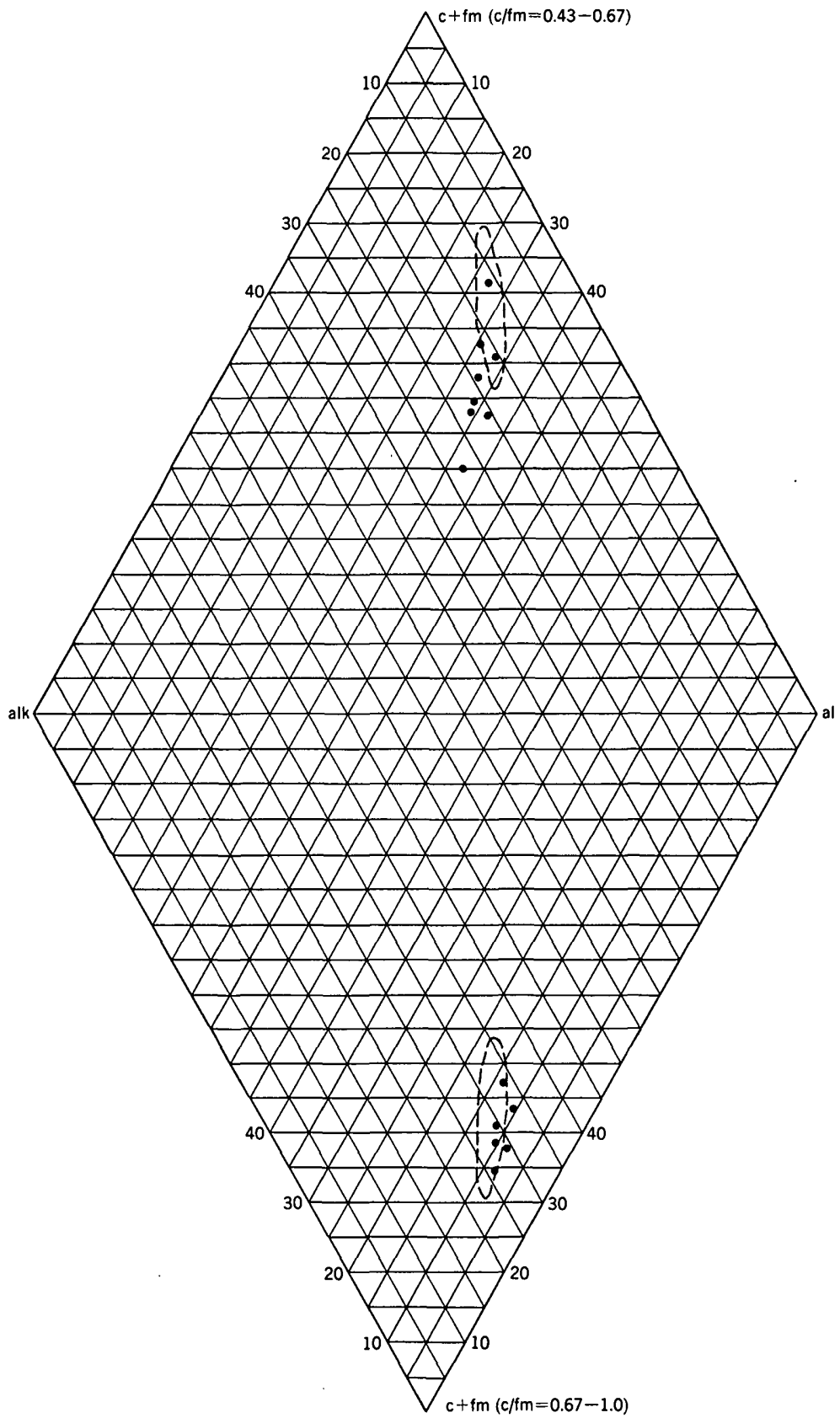

Figure 76.-Relations of al, alk, and $\mathrm{c}+\mathrm{fm}$ in volcanic rocks from Semisopochnoi Island, plotted in 2 sections of the Niggli tetrahedron that include the al-alk edge. Dashed line encircles positions of points representing all anslyzed rocks from Adak, Kanaga, and Buldir Islands. 


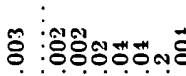

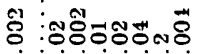

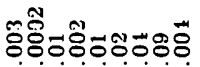

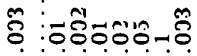

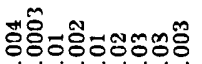

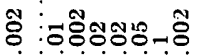

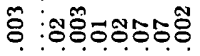

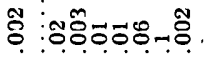

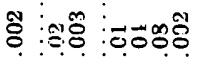

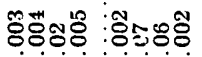

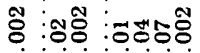

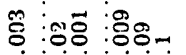

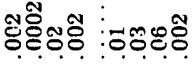

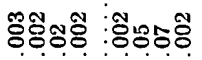

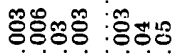

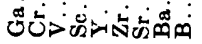

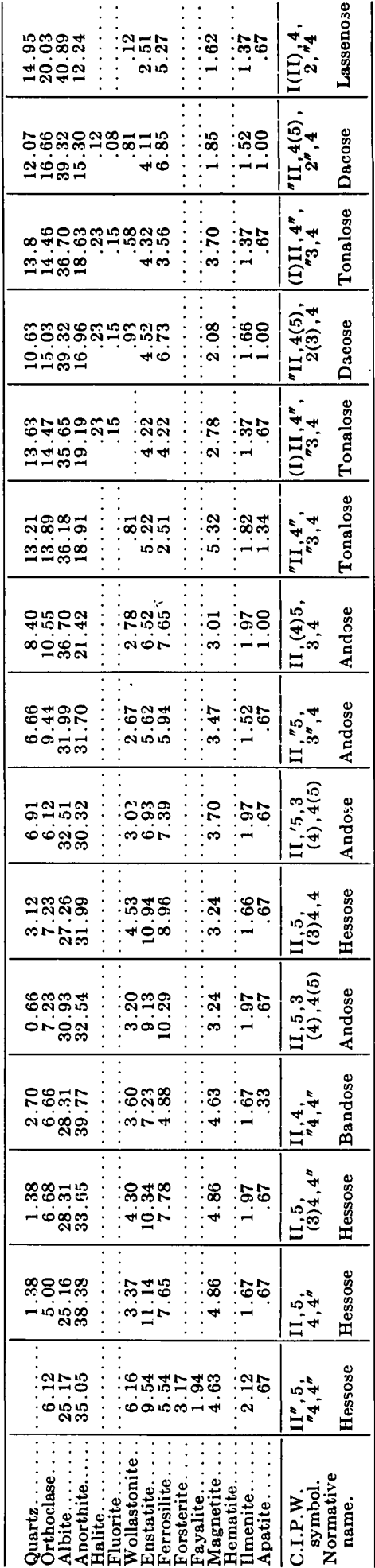


cally by K. J. Murata (Coats, 1952, p. 509). In the rocks of Buldir, Adak, and Kanaga, the ratio of strontium to barium seems independent of silica percentage, and dependent largely on provenance (Coats, 1953, p. 21) ; in the rocks from Semisopochnoi the ratio of strontium to barium shows a good deal of scatter.

Some average ratios in volcanic rocks from four Aleutian Islands are given below.

\begin{tabular}{|c|c|c|c|c|c|c|c|}
\hline \multirow{2}{*}{ Island } & \multicolumn{7}{|c|}{ Ratio of- } \\
\hline & $\begin{array}{c}\text { Cobalt } \\
\text { to } \\
\text { MgO }\end{array}$ & $\begin{array}{c}\text { Nickel } \\
\text { to } \\
\text { MgO }\end{array}$ & $\begin{array}{c}\text { Chromium } \\
\text { to } \\
\text { MgO }\end{array}$ & $\begin{array}{c}\text { Strontium } \\
\text { to } \\
\text { Barium }\end{array}$ & $\begin{array}{c}\text { Barium } \\
\text { to } \\
\mathrm{K}_{2} \mathrm{O}\end{array}$ & $\begin{array}{c}\text { Vanadium } \\
\text { to } \\
\mathrm{FeO}\end{array}$ & $\begin{array}{c}\text { Zirconium } \\
\text { to } \\
\mathrm{SiO}_{2}\end{array}$ \\
\hline $\begin{array}{l}\text { Kanaga ........ } \\
\text { Adak } \\
\text { Buldir.............. } \\
\text { Semisopochoi }\end{array}$ & $\begin{array}{l}4 \times 10- \\
4 \\
3 \\
7\end{array}$ & $\begin{array}{l}3 \times 10^{-} \\
3 \\
10\end{array}$ & $\begin{array}{l}3 \times 10^{-3} \\
3 \\
3\end{array}$ & $\begin{array}{l}0.7 \\
3 \\
2 \\
\quad .6\end{array}$ & $\begin{array}{l}3 \times 10^{-2} \\
3 \\
2 \\
6\end{array}$ & $\begin{array}{l}3 \times 10^{-3} \\
2 \\
2 \\
3\end{array}$ & $\begin{array}{r}1 \times 10^{-1} \\
7 \times 10^{-5} \\
8 \times 10^{-5} \\
20 \times 10^{-5}\end{array}$ \\
\hline
\end{tabular}

The ratios for nickel and chromium to $\mathrm{MgO}$ have been omitted for Semisopochnoi Island in the above compilation because many of the values were below the limit of detectability. In all probability differences of one in the first significant figure are not statistically significant; differences that are severalfold are believed to be genuine and significant.

\section{LITERATURE CITED}

Barnes, V. E., 1930, Changes in hornblende at about $800^{\circ}$ C.: Am. Mineralogist, v. 15, p. 393-417.

Becker, G. F., 1898, Reconnaissance of the gold fields of southern Alaska, with some notes on general geology: U.S. Geol. Survey 18th Ann. Rept., pt. 3, p. 1-86.

Bowen, N. L., 1947, Magmas: Geol. Soc. America Bull., v. 58, p. 263-280.

Byers, F. M., Jr., Hopkins, D. M., Wier, K. L., and Fisher, Bernard, 1947, Volcano investigations on Umnak Island, 1946: U.S. Geol. Survey Alaskan Volcano Inv., Rept. no. 2, pt. 3.

Coats, R. R., 1952, Magmatic differentiation in Tertiary and Quaternary volcanic rocks from Adak and Kanaga Islands, Aleutian Islands, Alaska: Geol. Soc. America Bull:, v. 63, p. 485-514.

1953, Geology of Buldir Island, Aleutian Islands, Alaska: U.S. Geol. Survey Bull. 989-A, p. 1-24.

- 1956, Geology of northern Kanaga Island, Alaska: U.S. Geol. Survey Bull. 1028-D, p. 69-80.

Cotton, C. A., 1944, Volcanoes as landscape forms: Christchurch, New Zealand, Wellington, Whitcombe and Toombs, Ltd., $416 \mathrm{p}$.

Daly, R. A., 1933, Igneous rocks and the depths of the earth: New York, McGraw-Hill.

Einarsson, Trausti, 1949, The flowing lava; studies of its main physical and chemical properties, V. 4, Pt. 3 of The eruption of Hekla, 1947-48: Reykjavik, Visindafelag Islendinga [Soc. Sci. Islandica], $70 \mathrm{p}$. 
Fenner, C. N., 1920, The Katmai region, Alaska, and the great eruption of 1912 : Jour. Geology, v. 28, no. 7, p. 569-606.

George, W. O., 1924, The relation of the physical properties of natural glasses to their composition: Jour. Geology, v. 32, p. 353-372.

Grewingk, Constantin, 1850, Beitrag zur Kenntniss der orographischen und geognostischen Beschaffenheit der Nordwest Küste Amerikas, mit den anliegenden Inseln: Russ. K. min. Gesell. Verh., St. Petersburg, 1848-49.

Hinds, N. E. A., 1925, Amphitheater valley heads: Jour. Geology, v. 33, p. 816-818.

Hunt, C. B., 1942, New interpretation of some laccolithic mountains and its possible bearing on structural traps for oil and gas : Am. Assoc. Petroleum Geologists Bull., v. 26, no. 2, p. 197-203.

Jaggar, T. A., 1931, Lava stalactites, stalagmite, toes, and "squeeze-ups": Volcano Letter no. 345, p. 1-3.

Kennedy, G. C., 1948, Equilibrium between volatiles and iron oxides in igneous rocks: Am. Jour. Sci., 5th ser., v. 246, p. 529-549.

- 1955, Some aspects of the role of water in rock melts in Poldervaart, A., ed., Crust of the earth-a symposium: Geol. Soc. America Spec. Paper 62, p. 489-504.

Kozu, Shukusuke, Yoshiki, Bunpei, and Kani, Koichi, 1927, Note on the study of the transformation of common hornblende to basaltic hornblende at $750^{\circ}$ C.; Tohoku Imp. Univ. Sci. Repts., ser. 3, v. 3, nos 2, 3.

Peacock, M. A., 1931, Classification of igneous rock series: Jour. Geology, v. 39 , p. $54-67$.

Poldervaart, Arie, 1949, Three methods of graphic representation of chemical analyses of igneous rocks: Royal Soc. South Africa Trans., v. 32, p. 177-188.

Simons, F. S., and Matthewson, D. E., 1955, Geology of Great Sitkin Island, Alaska: U.S. Geol. Survey Bull. 1028-B, p., 21-43.

Stearns, H. T., and Macdonald, G. A., 1946, Geology and ground-water resources of the Island of Hawaii: Hawaii Div. Hydrography Bull. 9.

Tsuboi, Seitaro, 1934, Some remarks on the petrology of the common volcanic rocks of Japan: Pacific Sci. Cong., 5th, Canada 1933, Proc., v. 3, p. 2271-2273.

Williams, Howel, 1935, Newberry volcano of central Oregon: Geol. Soc. America Bull., v. 46, p. 253-304.

- 1941, Calderas and their origin: California Univ., Dept. Geol. Sci. Bull., v. 25, no. 6, p. 239-346.

1942, The geology of Crater Lake National Park, Oregon: Carnegie Inst. Washington Pub. 540. 


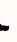

s

,

.

7

$r$ 


\section{INDEX}

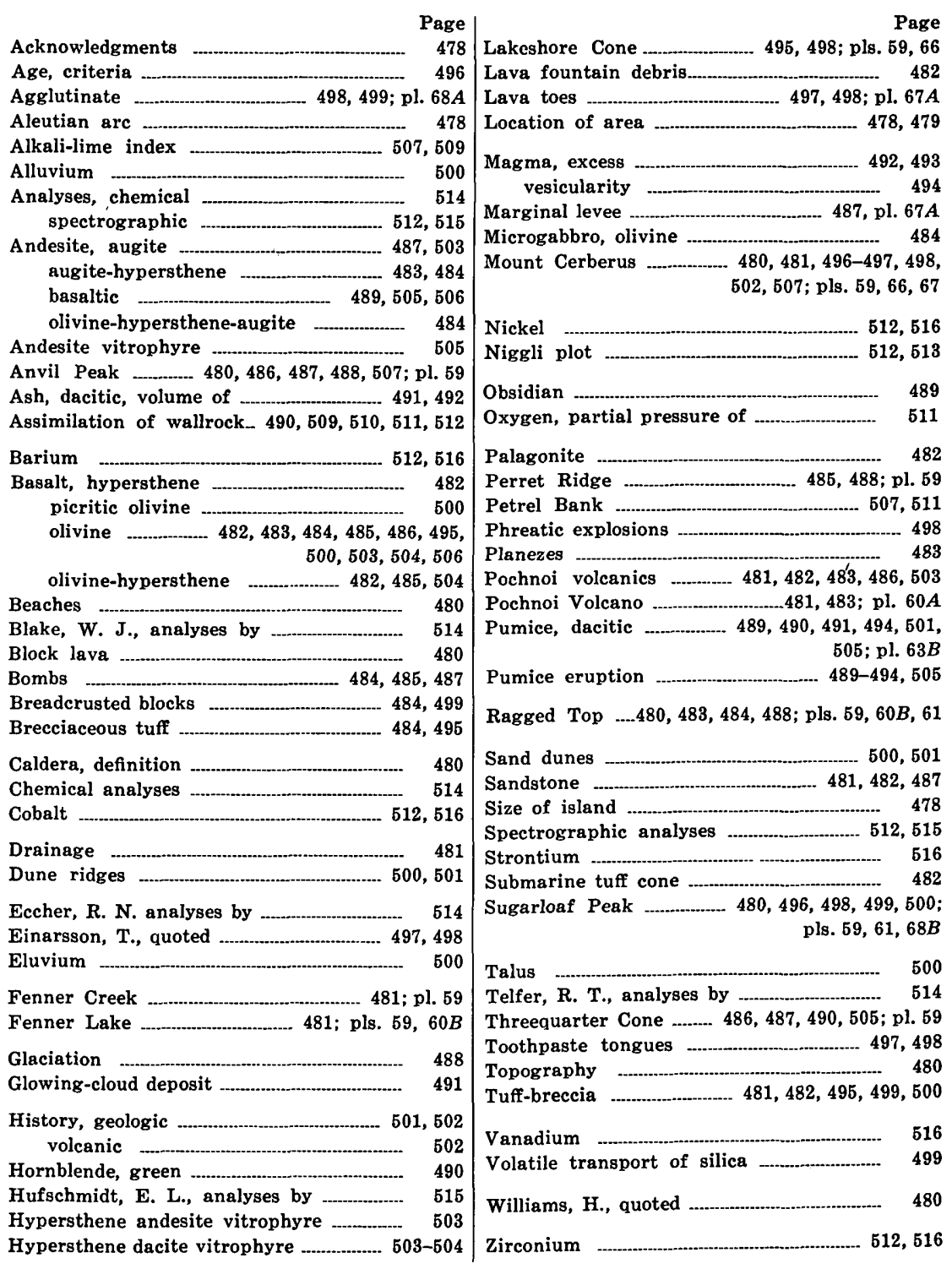

